\title{
STŘEDOVĚKÉ KACHLE S MOTIVEM LOVU NALEZENÉ V ČESKÉM SLEZSKU A JEJICH PROVENIENCE
}

\author{
MARTIN HLOŽEK - MARKÉTA TYMONOVÁ
}

Abstrakt: Lov divoké zvěre byl ve středověku vysoce prestižním způsobem zábavy aristokratických vrstev, který svou atraktivitou inspiroval nejen různé obory výtvarného umění, ale během 15. století pronikl i do reliéfní výzdoby kachlových kamen. Svědči o tom nálezy kachlù s žánrovými scénami z hradu Cvilína u Krnova a z města Opavy, kde se na výrobu kamnářského zboži specializovala hrnčǐrská dilna v Krnovské ulici na bývalém Jaktařském předměstí. Místni pưvod kachlové série naznačil petrografický rozbor keramické suroviny a některé shodné exempláre vyskytujíci se na obou lokalitách. Na Opavsku jde zatím o jediné archeologicky prokázané výrobni centrum.

Klíčová slova: lovecké motivy - kamnářská výroba - petrografické analýzy - hrad Cvilín Opava.

\section{Medieval tiles with hunting motifs from Czech Silesia and their provenance}

Abstract: Hunting for wild animals was a highly prestigious pastime in aristocratic circles in the Middle Ages. Its attractiveness inspired various art disciplines, and in the 15th century it also extended to relief decoration of tile stoves. This is evidenced by the finds of tiles with genre scenes from the Cvilin castle, near Krnov and from the town of Opava where a pottery workshop specialising in stove goods was located in Krnovská Street, in the former Jaktařské predměstí suburb. The local origin of the tile series was also indicated by the petrographic analysis of the ceramic material and by some identical specimens from both sites. In the Opava region, this has been the only archeologically excavated ceramic production centre so far.

Key words: hunting motifs - stove production - petrographic analyses - Cvilin castle - Opava.

\section{Úvod}

Lovecké aktivity náležely vedle turnajů a rytířských pasování k oblíbeným aristokratickým kratochvílím, které ve středověku tvořily běžnou složku společenského života. Nešlo jen o atraktivní zábavu, jež byla charakteristická pro životní styl vyšších vrstev, ale o součást výchovy, protože př́íslušníci elity museli ovládat řadu dovedností včetně jízdy na koni a zacházení se zbraní. Podle traktátu Disciplina clericalis od Petruse Alfonsa, španělského konvertity žijícího počátkem 12. století na dvoře anglického krále Jindřicha I., vzdělání dokonalého rytíře sestávalo ze sedmera ctností (septem probitates), k nimž se počítalo umění jezdit na koni (equitare), plavat (natare), stř́let z luku (sagitare), lovit (aucupare), bojovat se zbraní (certare caestibus), hrát šachy (ludere latrunculorum) a veršovat (versificare). Lovecká průprava byla tudíž nezbytná pro panské vychování, které vycházelo z křest’anských hodnot, promítajících se do ušlechtilých vlastností, jako byly udatnost a moudrost (fortitudo et sapientia), věrnost (fidelitas) nebo zbožnost (pietas). Rytířské ctnosti byly zakotveny v pravidlech dvorské etikety, manifestovány způsobným chováním vůči ženám, znalostí cizích řečí nebo uměním konverzace, s nimiž se rytířský dorost seznamoval ve službě na panovnických nebo šlechtických dvorech. Dosažení patřičného vzdělání bylo předpokladem $\mathrm{k}$ úspěšnému společenskému vzestupu, který pozitivně ovlivňovaly dobré majetkové poměry, starobylý původ či konexe (Nedvědová-Kolár 1983, 31; Dvořáčková-Malá-Zelenka 2011, 156, 250-261; Sawina 2015, 43-44; Velčev 2015, 52-53).

Vedle intelektuálních předpokladů hrála důležitou roli fyzická zdatnost v bojovém a loveckém umění, jež vyžadovaly dlouhodobou průpravu. Na rozdíl od turnajových klání, kde přímý střet hrozil vážným zraněním, ba i smrtí, lov až tak nebezpečný nebyl, ačkoli lovce konfrontoval s divokou zvěří či záludnostmi lesních hvozdů. Štvanice na vysokou a černou zvěř byly zdrojem 
dobrodružných zážitků a kromě uspokojení lovecké vášně přinášely také společenské kontakty, jelikož s nimi byly spojeny dvorské slavnosti a hostiny, využívané k diplomatickým jednáním, získání postavení, př́izně či kariérních výhod. Vedle toho hony poskytovaly i prozaické požitky, jelikož ulovená zvěřina byla vítaným darem anebo mohla skončit na slavnostních tabulích či v kuchyňských spižírnách. Nutno však podotknout, že hlavní důvod loveckých výprav nespočíval v rovině ekonomické, nýbrž společenské, poněvadž lov byl považován za důstojný způsob vyžití panstva (Stehlíková 1999, 210; Bůžek-Hrdlička-Král-Vybíral 2002, 343-345; Guerreau 2002, 368; Verdon 2003, 49-70; Žemlička 2005, 149-150; Čapský 2009, 209-210; 2014, 275276; Eberl 2015, 228-229, 233).

Význam lovu v životě privilegované společnosti dokládají žánrové výjevy z loveckého prostředí, ztvárněné nejen ve formě dřevorytů, iluminací, grafik nebo tapisérií (obr. 1), ale také v maliřrské, řezbářské nebo sochařské výzdobě. Atraktivní náměty z loveckého prostředí se staly natolik populární, že inspirovaly i tvůrce kachlové výzdoby. Tematicky však nejsou spojeny pouze s panskými sídly, ale vyskytují se i na kamnářských výrobcích pocházejících z měst a výjimečně i z klášterů. Rozšíření v různých sociálních prostředích naznačuje, že pro tuto aktivitu nehorovala pouze nejvyšší složka společnosti, čili panovník a šlechta, ale také duchovní osoby a zámožní patricijové, kteří se snažili napodobovat aristokratické způsoby. Na rozdíl od urozených, pro něž byla vyhrazena štvanice, méně privilegovaní zpravidla lovili zvěř naháněním do sítí, čímž ovšem šlechta pohrdala, nebot' tento způsob považovala za sebe nedůstojný. Lov zaměřený hlavně na maso proto praktikovalo spíše měštanstvo, jež mohlo lovit v městských lesích pouze menší druhy zvířat, zatímco vysoká a černá zvěř náležela elitě.

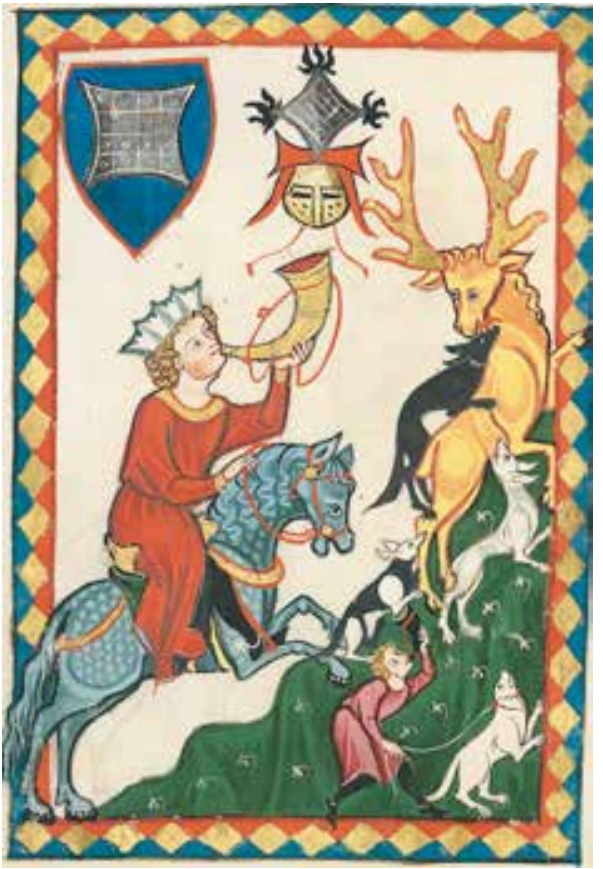

Obr. 1. Konrád ml. ze Sanecku na lovu. Zdroj Große Heidelberger Liederhandschrift (Codex Manesse), Universitätsbibliothek Heidelberg; Cod. Pal. germ. 848, p. 202v; dostupné z: http://digi.ub.uni-heidelberg.de/diglit/cpg848. Abb. 1. Konrad der Junge von Suonegge auf der Jagd. Quelle Große Heidelberger Liederhandschrift (Codex Manesse), Universitätsbibliothek Heidelberg; Cod. Pal. germ. 848, p. 202v; abrufbar unter: http://digi.ub.uni-heidelberg. de/diglit/cpg848.

Lovecké motivy na kachlích neměly z ikonografického hlediska pouze profánní význam, ale obsahovaly i ideové sdělení, poněvadž lov byl z hlediska křestanské věrouky chápán jako činnost pozitivní, která člověka odváděla od hříchu. Symbolické významy připisované lesním zvířatům, zvláště byly-li ve spojení se světci, vyjadřovaly boj dobra se zlem a $v$ přeneseném slova smyslu ztělesňovaly protiklad božských sil vůči d’ábelským svodům. Nešlo jen o prezentaci panské zábavy, jež skrze kachlové reliéfy vstupovala do nearistokratického prostředí, ale díky skryté symbolice rovněž o demonstraci poselství s mravoličným obsahem. Výběr motivů závisel na přání objednatele a možnostech výrobce, na němž spočívalo zajištění formy, která později sloužila k výrobě dalších kachlů. Šiŕrení motivů ovlivňovala i běžná dílenská praxe, jelikož hrnčíři s kachlovými formami obchodovali nebo si je vyměňovali a také je dědili.

\section{Historie a organizace lovu}

Lov sloužil primárně k zajištění lidské obživy, avšak s osvojováním zemědělství ztrácel na významu a stával se pouze doplňkovým zdrojem obživy. V pravěku a zčásti ještě v raném středověku podíl ulovené divoké zvěře v jídelníčku kolísal, avšak od vrcholného stř̌edověku jako hlavní způsob získávání 
potravy nefiguroval (Kyselý 2015, 226-227). Snižující se intenzitu loveckých aktivit nepříznivě ovlivňovalo odlesňování krajiny v průběhu agrární, městské a hornické kolonizace, v jejichž důsledku se les využíval k pastvě nebo jako zásobárna dříví a řemeslnicky využitelných komodit. Ustanovení týkající se lesa známe již od velkomoravského období, kdy se zakazovalo kácení stromů a žhářství. V přemyslovském státě se ochrana zaměřila především na pohraniční hvozdy zajišt'ující obranu země a na revíry využívané $\mathrm{k}$ loveckým účelům, jež tvořily součást zeměpanské ekonomiky. Př́islušné zmínky obsahují Statuta Konráda Oty z roku 1189 a také návrh zákoníku Maiestas Carolina, sepsaný okolo roku 1350 z popudu císaře Karla IV. První lesní ráa stanovující tresty za nedovolené kácení a poplatky za dřevo byl v Čechách vydán až v roce 1397 a platil pouze pro Chebsko (Nožička 1957, 36-37; Beranová 2000, 111-112; Leiendecker 2004, 10; Klápště 2005, 177-180; Trachtová 2008, 20-22; Mileson 2009, 28; Boháček 2011, 539; HédlSzabó-Riedl-Kopecký 2011, 62-63; Žemlička 2012, 7-8; 25-26; Hudáček 2014, 76-79; Vašica 2014, 194, 221; Janišová-Janiš 2015, 416; Vaníčková-Žemličková 2015, 9-14).

Vyčleňování souvislých lesních ploch k loveckým účelům začali od 7. století praktikovat merovejští panovníci v rámci dynastického majetku v Ardenách a Vogézách, ležících na pomezí dnešní valonské části Belgie a východní Francie. Jelikož využivání těchto území zajištovaly z hlediska přírodních zdrojů, možnosti lovu a správy formou beneficií prostředky pro fungování státní moci, v budování lesních komplexů pokračovali i Karlovci a Ottonci. Podle nařízení Karla Velikého $(\dagger$ 814) v Capitulare de villis vel curtis imperii měli péči o lesy na starosti správci (custoditae silvae vel forestes) a organizování honů lovci (venatores). Když se v 10. století královská půda dostávala do rukou lenníků, lesy kolem ottonských falcí začali obhospodařovávat místní aristokraté, kteří si budovali vlastní dominia s loveckými revíry. Avšak i na těchto územích zůstávalo lovecké právo (iura ducalia) i nadále monopolem panovníka (Boretius 1883, MGH 83, 86-87; Zotz 1997, 102-107; Jan 2000, 193; Guerreau 2002, 369; Ergert 2004, 94; Čapský 2014, 278-279; Lysá 2014, 119).

Obdobný proces se od 10. a v 11. století postupně nastartoval i v českém státě, kde lovecké právo tvořilo součást zeměpanských privilegií, avšak na územích mimo panovníkovu doménu se až do 12. století striktně nevymáhalo. Se vznikem moravských údělů v polovině 11 . století začaly loveckou výsadu užívat linie moravských Přemyslovců a po vyčlenění Opavska ve druhé polovině 13. věku také tamní legitimizovaná větev, požívající od roku 1318 titulu opavských knížat. Od druhé poloviny 12. století mohla skrze majetkové donace lovit i šlechta, klérus a později obyvatelé měst. Na darovaných či propůjčených statcích si však panovník ponechával přednostní právo, případně mohl požadovat plnění určitých služeb (Chadt-Ševětínský 1908, 136; Jan 2000, 192; Žemlička 2002, 340; 2012, 10, 15; Janišová 2014, 104).

Lovecké revíry zřizovali Přemyslovci po franském vzoru v zemědělsky nevhodných terénech, které byly snadno dosažitelné ze sídelního města. Nejčastěji navštěvovali lesy v povodí Berounky (dříve Mže), kde na přelomu 10. a 11. století nechali zbudovat knížecí dvůr ve Zbečně a později hrad Křivoklát, následovaný menšími hrádky, jako byly Týřov, Jivno, Nižbor, Hlavačov a další. Kromě křivoklátských hvozdů se vydávali i do středního Povltaví, dolního Posázaví nebo do vzdálenějších koutů na severozápadě a východě země. Od druhé poloviny 13 . století začali zakládat hrazené obory; první zřídil Přemysl Otakar II. na místě pražské Stromovky. Správou královských lesů byl pověřen hlavní lovčí, čili lovmistr (summus venator regis, praefectus super venatores), jemuž byli v jednotlivých revírech podřízeni lesní (custodes silvae) a lovčí (magister venatorum), kteří měli k ruce pomocný personál (Chadt 1907, 4; Andreska-Andresková 1993, 25; Durdík 1997, 237, 298; Žemlička 1997, 178; 2002, 528; 2004, 13-14; Ježek 1999, 269, 293; 2012, 240-241; Vaníčková-Žemličková 2015, 23-24).

Moravské honební revíry se podle kronikáře Kosmy nacházely v dosahu hradských center, což naznačuje poznámka o Olomoucku vhodném pro lovectví. Další komplexy vznikly v Chřibech (s centrem na pozdějším Buchlově), na Českomoravské vrchovině (královský dvorec v Jaroměři) a v podhůří Hrubého Jeseníku (hrad Úsov). Lovecké záležitosti v každém z údělů obstarával lesní úřad řízený lovčím (beneficium forestarii) a od 20. a 30. let 13. století dvorským lovčím (venator curialis, summus venator), podřízeným od následujícího věku královskému 
správci pro Čechy i Moravu (Jan 2000, 193-194, 198; Žemlička 2002, 510; 2012, 8; Vaníčková-Žemličková 2015, 16-17).

Na Opavsku se lovné areály soustředily v jižní části země situované na moravsko-slezském pomezí, jež byla od poslední čtvrtiny 12. století pod kontrolou českých králů. Lesy se táhly od výběžků Nízkého Jeseníku u sídelního Hradce k Vikštejnu a od Cvilína dál do nitra horského masivu k hradu Fürstenwalde. Mimo to využívali opavští Přemyslovci lesy na Ratibořsku, které rok po smrti bezdětného knížete Leška († 1336) připadlo Mikuláši II. Opavskému († 1365). Jelikož jeho první ženou byla Leškova sestra Anna, knížectví zdědil nejstarší syn Jan I., jenž roku 1377 ke svému dílu připojil i Krnovsko a Bruntálsko. Kromě rezidenčního hradu v Ratiboři sloužily k loveckým aktivitám i klášterní majetky, především cisterciácký klášter v Rudách, poskytující knížeti a jeho personálu služby a zázemí (Mika 2000, 11-12; Čapský 2005, 46; 2009, 218; 2014, 278; Biel 2013, 10; Čapský-Prix 2012, 286, 335).

Lov soustředěný kolem knížecích hradů měli na starosti purkrabí, kteří dohlíželi na udržování revírů, organizování honiteb a nahánění zvěře. Za věrné služby mohli získat značné majetky, jako tomu bylo v př́ípadě poloviny Leskovce (Spachendorf) u Horního Benešova, kterou Přemysl Otakar I. obdaroval svého lovčího. O lesní půdu měly zájem nejen církevní instituce, jak na to poukazuje donace Stěbořického újezdu Velehradskému klášteru v roce 1228, ale i města. V roce 1271 získala čtyřicet lánů skřípovského lesa Opava a o deset let později obdrželi 24 lesních lánů u Opavice Krnovští od Mikuláše Opavského, jehož potomci požívali lovecký regál jak na městském, tak na církevním zboží. To se však netýkalo Krnovska, které v roce 1493 získal v léno Jan z Šelmberka, od jehož potomků krnovské knížectví koupil v roce 1524 Jiří Braniborsko-Ansbašský z franské větve Hohenzollernů (Fukala 1998, 136-137; Čapský 2006, 126; 2009, 216-220; 2013, 109-110; 2014, 279-282; Žemlička 2012, 8-10; Eberl 2015, 229).

Navzdory vzrůstající majetkové moci šlechty určoval pravidla lovu až do 15. století král. Aby se omezil hromadný odchyt zvěře, zakázal markrabě Karel v roce 1341 lov jelenů a jiné zvěře do tenat (loveckých sítí) v celém království. Jeho syn Václav IV. pak v roce 1388 uznal lov za panskou výsadou, kterou si mohla na základě vlastnictví nebo držby pozemkového majetku nárokovat také šlechta, církev a města. Předpisy týkající se lovectví byly formou královských nařízení vtěleny do první česky psané právní příručky, tzv. Rožmberské knihy, dochované v opise z roku 1359, jejíž autorství je připisováno Petrovi z Rožmberka. V 15. století se do rozhodování o loveckých záležitostech zapojily také sněmy, jejichž usnesení byla shrnuta v tzv. Tovačovské knize, sepsané nejvyšším moravským hejtmanem Ctiborem Tovačovským z Cimburka. Celozemskou kodifikaci přineslo až Vladislavské zemské zř́izení z roku 1500, které po třiceti letech redigoval Ferdinand I., jenž si v něm vyhradil lovecký okrsek v obvodu jedné míle od Prahy. Po Bílé hoře se stal lov výhradně záležitostí společenské reprezentace, a $\mathrm{k}$ tomuto účelu si šlechta začala zřizovat hrazené obory, kde se zvěř chovala nikoli toliko kvůli panským kratochvílím, ale i pro maso (Horna 1922, 43; Kovařík 1989, 103; 1993, 10-11; Samsonowicz 1991, 175; Jan 2000, 195-198; Žemlička 2002, 510; 2012b, 8; Šimůnek 2008, 307; Janišová 2014, 105; Janišová-Janiš 2015, 414-420; Vaníčková-Žemličková 2015, 16-17).

\section{Lovecké techniky}

Lovecká strategie kopírovala vlastnosti a chování divoké zvěře, od čehož se odvíjel taktický postup směřující $\mathrm{k}$ získání kořisti. Ve středověké praxi se osvědčily tři základní způsoby lovu - pomocí lidí (cum homini), se psy (cum tubam) a s ptáky (cum avibus). Na dvorech německých císařů se praktikovala hlavně naháňka, při níž se zvěř pomocí loveckého personálu nasměrovala proti lovci, se kterým se nadháněči dorozumívali zvukovými signály. Ve Francii, kolébce dvorské kultury, byla nejoblíbenější honitba, tedy štvanice se smečkami psů, jejichž výcvik měli na starosti psáři čili psovodi (caniferi, caniductores). Protože k ulovení různých druhů zvěře bylo zapotřebí odlišné taktiky, v královských a knížecích sídlech byl obvykle zaměstnáván větší počet specializovaných lovců. Na dvoře Karla Velikého lovecké záležitosti obstarávali čtyři lovčí (venatores principales) určení pro velká lesní zvířata (bersalius), menší zvěř (beverarius) a polní 
zvířectvo (veltrarius). Dravé ptáky měl na starosti sokolník (falconarius), jenž zajištoval i jejich výcvik (Rösener 1997, 118-119; Bezděk 2001, 15; Krivjanský 2007, 27).

Honitba - coby společensky nejprestižnější způsob lovu - kladla vysoké nároky na jezdecké umění, které vyžadovalo dokonalou součinnost lovce, koně a psa. Od koní vycvičených k lovu (leporarii) se vyžadovala rychlost, obratnost, odvážnost, poslušnost a schopnost překonávat terénní překážky. Na rozdíl od pozdějších parforsních honů (z franc. par force, tj. ulovit silou až do uštvání), praktikovaných od poloviny 17 . století v uzavřených oborách, honitby neměly pevně stanovená pravidla a odehrávaly se ve volné krajině. Jejich cílem nebyl jen jeden předem vybraný kus, ale vedle jelena i jiná zvířata - srnci, medvědi, divoká prasata, vlci nebo lišky. U distančních lovů se ke skolení používaly luky a šípy, které od počátku 14. století nahradily údernější kuše, archeologicky doložené kostěnými ořechy spouštěcího mechanismu nebo kostěným obložením sochy. Za lovecké bývají považovány hroty šípů s rozeklanými hroty, jež se našly v roce 2013 zabodnuté ve svazích Devínské Kobyly, příslušející k loveckému revíru slovenského hradu Devín. Vedle mechanických militarií se k lovu používaly i palné zbraně rozšířené po husitských válkách, užívané k lovu od 16. a v 17. století. Ke kontaktnímu lovu pak sloužily hlavně kopí, velké nože nebo tesáky, ale z ikonografie jsou známy i meče (Dušek 1995, 85; Redolfi 2002, 62; Farkaš 2013, 158).

Ke komunikaci lovců s loveckým personálem se používaly hlavně lovecké rohy, vyráběné od 12. a 13. století z rohoviny, slonoviny nebo drahých kovů, které dokládají iluminace v tzv. Velkém heidelberském zpěvníku (Codex Manesse) z let 1300-1350 s výjevy z dvorského prostředí. Popisem lovu jelena začíná Kniha krále Moda a královny Ratio (Livre du roi Modus et de la reine Ratio), sepsaná na objednávku normandského šlechtice Henriho de Ferrières mezi lety 1360-1379, v níž byly formou dialogu popsány lovecké praktiky a charakteristiky divokých zvířat. Za nejušlechtilejší lesní zvíře byl považován jelen, symbol Ježíše Krista, který na rozdíl od divokého prasete nebo medvěda lovce chránil, jak na to poukazují legendy o sv. Jiljí, Eustachovi nebo Hubertovi. Další pojednání zaměřené na lov se psy vyhotovil v letech 1387-1389 pro burgundského vévodu Jana Nebojácného Gaston Phébus (obr. 2). V bohatě iluminované Knize o lovu (Livre de la chasse) popsal hrabě z Foix vzhled, chování a způsob života divokých zvírat. Samostatnou kapitolu věnoval přípravě psovodů a výcviku psů, z nichž byl vysoce ceněn chrt (vertragus), jehož starobylý původ naznačily osteologické nálezy z druhé poloviny 8 . století, zjištěné při výzkumu hradiska Chotěbuz-Podobora u Českého Těšína. Mladší nález z 16. století pochází ze zámku ve Ždánicích, kde byl psí skelet zazděn ve stropu mezi sálem a věží. V naší historické produkci obsahuje popisy divokých zvířat Kniha dvacatera umění (Liber viginti arcium), sepsaná Pavlem Žídkem (Paulerinus) kolem roku 1460 pro Jiřího z Poděbrad. Podle tohoto autora byl za lovce pokládán ten, kdo chytal lesní zvířata a do kuchyně dodával jejich maso (Redolfi 2002, 62; Dvořáková 2007, 76; Nývltová-Fišáková 2007, 29-30; Matolínová 2007, 30-32; Hadravová 2008, 65; Čapský 2014, 278; Pírek 2014, 126-127; 2015, 199).

Elitní význam lovu dokládá ve středověkých kontextech výrazná převaha kostí domácích zvířat nad kostmi zvířat divokých, jejichž podíl v souborech získaných z raně středověkých hradišt' jižní Moravy činil okolo $5 \%$. Obdobné výsledky byly zaznamenány při výzkumu olomouckého Povelu nebo Předhradí a také z Čech i Německa. V mladších vrcholně středověkých celcích pocházejících z českých lokalit byla divoká zvířata nejpočetněji zastoupena v souborech z panských sídel $(6,9 \%)$, méně z měst $(1,8 \%)$ a vesnic $(1,4 \%)$ (Samsonowicz 1991, 168-175; 1994, 6; 1995, 60; Rakušan 1999, 13; Redolfi 2002, 62; Galuška 2004, 35; Waingertner 2004, 178; Žemlička 2012a, 202, 220-222; Vaníčková 2012, 39; Janišová 2014, 104-105; Šín 2014, 52; Vaníčková-Žemličková 2015, 56).

Co se týče druhového zastoupení, v raně středověkých souborech hradištního typu se nejčastěji vyskytovaly kosti jelena, srnce, prasete, zajíce, pratura, bobra, medvěda, losa, veverky, lišky, jezevce a rysa; pouze na sídlištích byli doloženi menší predátoři jako vydra, lasice, hranostaj či tchoř. Od vrcholného středověku divoká zvířata převažovala hlavně na panských sídlech, kde se lovil zajíc, jelen, srnec a prase divoké; výjimečně veverka, liška, medvěd, bobr a jezevec. Skladba se však na jednotlivých lokalitách lišila, takže na hradě v Lelekovicích (14. století) se 


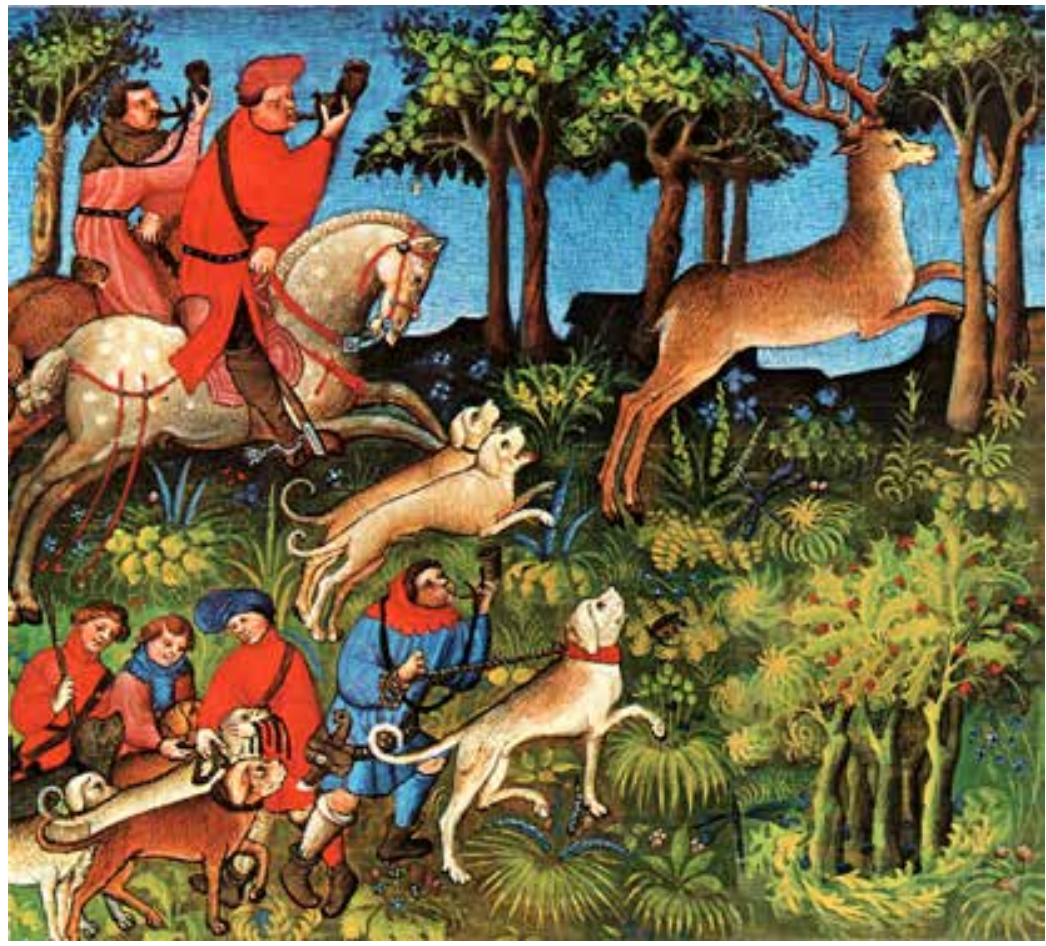

Obr. 2. Gaston Phébus, Lovecká scéna z Knihy o lovu. Zdroj Livre de la chasse, Paris, BnF, Département des manuscrits, Français 616 f. 68; dostupné z: http://classes.bnf.fr/phebus/grands/c39_616.htm.

Abb. 2. Gaston Phébus, Jagdszene aus dessen Buch von der Jagd. Quelle Livre de la chasse, Paris, BnF, Département des manuscrits, Français 616 f. 68; abrufbar unter: http://classes.bnf.fr/phebus/grands/ c39_616.htm.

nejčastěji vyskytl jelen, zubr, pratur, srnec, prase, vlk, bobr, drozd, kvíčala nebo holub. Na hradě Skály, kam se úlovky donášely kompletní, byl pro první polovinu 15 . století doložen jelen, srnec a zajíc. V hornickém sídlišti v Glanzenbergu (Staré mesto) v Banské Štiavnici činil podíl lovných druhů 3-9\% s dominancí jelena, což podtrhuje ekonomický význam tohoto zvířete z hlediska konzumace (Macek 2001, 281; Redolfi 2002, 62; Mlíkovský 2003, 361; Kyselý 2005, 53-54; 2005a, 80-83, 87, 89; Nývltová-Fišáková 2011, 51-54; Vaníčková 2012, 45; Vaníčková-Žemličková 2015, 53-54; Bielichová-Labuda 2017, 37, 43, 48, 58).

Divoká zvířata se ovšem nelovila jen kvůli masu nebo trofejím, jejichž úprava byla ve 13. a 14. století prokázána na hradě Tetíně, ale také kvůli sekundárním produktům v podobě kůže nebo parohoviny. Nejžádanější byla ovšem zvěřina, považovaná za luxusní jídlo určené pro privilegované vrstvy, o jejíž dostatek se starali hajní. Prodávala se však také na městských tržištích, jako kupříkladu na Koňském trhu v Praze, kde byla k mání většinou v sobotu. Dodávky z městských lesů obstarávali zpravidla měšt’ané, naopak poddaní měli lovení zakázáno, nebot' pytláctví se ve středověku považovalo za krádež, která se trestala pokutou a ve zvlášt' závažných prrípadech i smrtí. Svědčí o tom případ Vaška Jurků z Březovic, zaznamenaný v Černých knihách loveckého práva hradu Buchlova z let 1617-1654, jehož roku 1562 oběsili v „,kožich srnich“ a nad ním přibili jelení parohy jakožto symbol spáchaného skutku. Sankce za pytlačení byly velmi přísné, poněvadž právně potvrzovaly výjimečný status lovecké činnosti (Winter 1892, 424; Macek 2001, 251; Krejčí 2007, 136, 142; Matolínová 2007, 30; Durdík 2010, 56). 
Menší druhy zvěře, jako bylo srnčí, zajíci nebo bažanti, se lovily pomocí dravých ptáků, nejčastěji z druhu sokolovitých (Falconidae) nebo jestřábovitých (Accipitridae), jejichž odchyt a výcvik měli na starosti sokolníci. Tento specifický způsob lovu byl původně rozšśřen ve středoasijských stepích a v oblasti Blízkého východu, odkud se v průběhu 5. století přenesl do Evropy. Během následujícího věku zdomácněl na panovnických dvorech, kde se mu oddávaly také urozené ženy a duchovní (Bogacki 2003, 13; Zelenka 2014, 410).

Hmotné památky svědčící o loveckém využití dravých ptáků máme doloženy již v období staré Moravy v podobě bronzového nákončí se stojícím sokolníkem z druhé poloviny 8 . století ze slovenského Moravského Jánu. Na Velké Moravě tuto zálibu dokládá o století mladší stříbrná plaketa ze Starého Města s jezdcem a dravcem, biologicky určeným jako papoušek, což lze připsat silně „,byzantinizující“ stylizaci, naznačující původ motivu. Sokolnictví kromě ikonografických pramenů dokládají také Fuldské anály, podle nichž se sokolem lovil kníže Svatopluk († 894) a s jestráábem učený Konstantin († 869), jak líčí legendické pojednání o světcově životě. Podle osteologických rozborů se od raného středověku k lovu nejčastěji využívali jestřáb a káně; v Mikulčicích také sokol a ve Staré Boleslavi krahujec a poštolka. V polském Slezsku se v hradištních souborech nejčastěji vyskytli jestřáb, krahujec, myšilov, poštolka a orel (Dekan 1979, 83, 175, obr. 66, 131; 1980, 66, obr. 24; Galuška 2002, 452; Bogacki 2003, 87; Mlíkovský 2005, 185-192; Krivjanský 2007, 25, 28; Profantová 2008, 96-97; Ivanič 2011, 66; Lysá 2014, 115-118; Vaníčková-Žemličková 2015, 39-40).

Četné dravce nalezneme také na známé tapisérii z Bayeux zobrazující dobytí Anglie normandským vévodou Vilémem v roce 1066, kde opeřenci sedící na rukách šlechticů jedoucích za

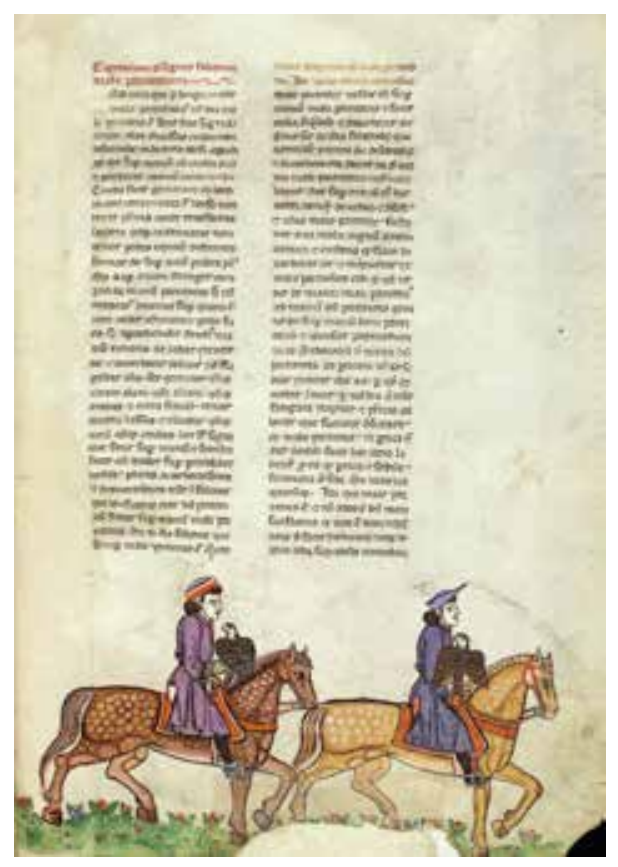

Obr. 3. Císař Fridrich II. na lovu. Zdroj ,Manfredův rukopis" De arte Venandi cum avibus. Vatikan, Biblioteca Apostolica Vaticana, Pal. lat. 1071, p. 103r; dostupné z: http:// digi.ub.uni-heidelberg.de/diglit/bav_pal_lat_1071/0209.

Abb. 3. Kaiser Friedrich II. auf der Jagd. Quelle „Manfred-Handschrift" De arte Venandi cum avibus. Vatikan, Biblioteca Apostolica Vaticana, Pal. lat. 1071, p. 103r; abrufbar unter: http://digi.ub.uni-heidelberg.de/diglit/ bav_pal_lat_1071/0209. vévodou Haroldem II. Godwinsonem představují symboly nejvyššího společenského statusu. O rozšíření sokolnictví na evropském kontinentu se zasloužili především franští a němečtí panovníci, jako byli Karel Veliký nebo Jindřich I. († 936), nazývaný díky této zálibě Ptáčník. Sokolnictví propadl také Fridrich I. Barbarosa († 1190), jenž si z kř́ížové výpravy přivezl kromě vzácných opeřenců i několik arabských chovatelů. Za uznávaného odborníka byl považován i jeho vnuk Fridrich II. $(†$ 1250), jemuž Teodor z Antiochie přeložil arabský traktát Kniha sokolníka Moamina o vědě, jak lovit pomocí ptáků a čtyřnohých zvírat (Liber Moamin falconarii de scientia venandi per aves et quadrupedes), opírající se o starší knihy al-Gitrifa a ibn Abdalláha al-Bázyára z 8. a 9. století. Poznatky o chování dravců a metodách jejich výcviku popsal císař v proslulém spise $\mathrm{O}$ přirozenosti ptáků a umění lovu s ptáky (De natura avium et arte venandi cum avibus), jehož originál se bohužel nedochoval. Jediným dokladem zůstává opis pořízený císařovým nemanželským synem Manfredem, z něhož čerpali pozdější autoři (obr. 3). Mezi jinými i italský učenec Petr de Crescentiis, jenž sepsal okolo roku 1300 dvanáctidílné zemědělské kompendium Ruralium commodorum libri XII, v jehož desátém svazku se píše o lovu a rybolovu. V Německu se dravými ptáky zabývala Sokolnická knížka 
(Das Ansbacher Beizbüchlein), pojednávající o výcviku jestřábů, která byla po několikerém přepracování vydána tiskem v roce 1480 v Augsburku (Teren-Rusina-Molnár 1988, 38-46; Samsonowicz 1991, 207; Fried 1997, 149-161; Redolfi 2002, 62; Bogacki 2003, 8; Lysá 2015, 443-444; Krivjanský 2007, 38-44; Eberl 2015, 231).

Draví opeřenci ztělesňující sílu, odvahu a obratnost se využívali především k lovu ve volné krajině. Ceněn byl zvláště sokol, považovaný za symbol rytířstva, a tudíž za obraz „vita akti$v a$ “ v protikladu k mnišskému „vita contemplativa“, symbolizovanému holubicí. Sokolnictví jako společensky prestižní činnost byla vyhrazena pouze nejvyšším aristokratickým vrstvám, zatímco lov se psy mohli praktikovat i měštané. Dobře vycvičení dravci byli vysoce ceněni, protože zosobňovali urozenost, bohatství a společenské postavení. V diplomatických stycích se využívali jako drahocenné dary vyjadřující úctu vůči obdarovanému, a proto byla po ušlechtilých opeřencích na královských a knížecích dvorech velká poptávka. Výborným výcvikem prosluli němečtí rytíři, od nichž v roce 1384 získal několik kusů braniborský markrabě Fridrich I. († 1440), který byl spolu se svým synem Albrechtem Achillem († 1486) vášnivým sokolníkem. Podobně v roce 1401 učinil český král Václav IV., jenž proslul velkým loveckým zápalem. Osm desítek sokolů v roce 1480 obdržel i římský papež Sixtus IV. a roku 1502 o vzácné pernatce požádal také německý císař Maxmilián I. Sokolnictví spojené se zálibou v koních, ušlechtilých ohařích nebo chrtech se pěstovalo na dvoře hlohovského a opavského knížete Zikmunda $(† 1548$; od roku 1506 polský král Zikmund I. Starý), jenž do roku 1502 pobýval v budínské metropoli u bratra Vladislava Jagellonského. Tam jako panovníkův nejbližší příbuzný byl často obdarováván; dva sokoly dostal od Ference Harasta a anglické ohaře od nitranského biskupa Mikuláše. Koně nejen dostával, ale sám je na trhu v Pešti i nakupoval, a když se na čas přesunul do Slezska, zaměstnával na svém dvoře lovčího Mathuse. Jako dary sloužily kromě dravých ptáků, koní nebo psů i lovecké zbraně, jak poukazuje kuš, kterou dostal vratislavský biskup Konrád od velmistra řádu německých rytírů. S ohledem na duchovní status olešnického knížete šlo zřejmě o zbraň určenou k účelům loveckým, a nikoli vojenským (Teren-Rusina-Molnár 1988, 38-46; Samsonowicz 1991, 207; Fried 1997, 149-161; Redolfi 2002, 62; Bogacki 2003, 8, 55-56; Čapský 2009, 211; 2014, 278; Lysá 2014, 117; 2015, 443-444; Krivjanský 2007, 38-44; Eberl 2015, 231).

Hmotné doklady chovu dravých ptáků jsou vedle písemných a ikonografických památek velmi vzácné. Výjimečný nález představují dva kotce s čelní stěnou vypletenou drátěným pletivem z počátku 15. století, identifikované v manském domě na hradě Křivoklátě. Praktikování sokolnictví pak dokládají nálezy zbytků kožených rukavic, které byly v Německu a ve Francii víceprsté a v Polsku jednopalcové. Poukazuje na to fragment nalezený ve vrstvě ze 14. století v polském Kolobřehu, vyzvednutý spolu s kusem tkaniny považovaným za součást sokolníkova kaftanu. Další zbytky rukavic se vyskytly v krakovském Vavelu, Vratislavi, Varšavě, Gdaňsku a Kališi. Známé jsou i z nalezišt' v Moskvě, Pskově a Novgorodu, kde se našly i zvonečky sloužící k lokalizaci ptáků. Tato funkce je u nás připisována rolničkám, avšak jejich sokolnické využití nelze spolehlivě prokázat (Durdík 1988, 292; 2010, 56; Bogacki 2003, 55, 77-78; Kozák 2009, 224, 232-233; Eberl 2015, 231-232).

\section{Ikonografie loveckých kachlů}

V životě elitní složky společnosti zaujímal lov důležité místo, a proto se nelze divit, že žánrové motivy zachycující tuto oblíbenou kratochvíli ožily i na stěnách kamen. Na reliéfních plochách kachlů byli lovci vypodobněni jednak jako jezdci se psy pronásledující zvěř, jednak jako sokolníci s loveckým rohem; málokdy jako pěší. V samostatných scénách vystupovala také lovená zvířata v podobě jelena, prasete nebo zajíce, a to většinou v doprovodu honicích psů. Výjevy mívaly náboženský podtext se skrytým morálním ponaučením, vyvozovaným ze zvířecích symbolů na základě interpretace podle bible, bajek, exempel a středověkých bestiářů. V nejznámějším Fysiologu, sepsaném ve 2. století v řečtině a přeloženém do latiny okolo roku 700, byla zvířata nejen vyobrazena, ale i popsána z reálného, alegorického a morálního hlediska (Treu 1981; Royt-Šedinová 1998, 201). 
Za nejušlechtilejší lesní zvíře byl pokládán jelen, považovaný v antice za posvátné zvíře bohyně lovu Artemidy. Protože byl ztotožňován s Ježíšem Kristem, měly jeho parohy symbolizovat desatero přikázání, ztělesňujících deset christologických vlastností, které lovce ochraňovaly před hříchem. Pronásledování pak personifikovalo boj dobra a zla, jež bylo zosobněno prostřednictvím kladně a záporně chápaných zvířat. Mezi kladná byl řazen sokol, jemuž byly připisovány vlastnosti ideálního rytíře, naproti tomu medvědovi a praseti byly přisouzeny vlastnosti veskrze negativní. Značně odpudivě bylo popisováno prase, jež bylo zvíře ošklivé, slintající a páchnoucí, které žilo v temnotách, bylo zrádné, plné pýchy a zloby. Myslelo pouze na pozemské slasti, bylo špinavé a líné a nacházelo potěšení v bahně; bylo nepřítelem Krista a vtělením d’ábla. Naproti tomu zajíc byl popisován neutrálně, jako zvíře bázlivé, které se neumí rozhodnout (Royt-Šedinová 1998, 142; Matolínová 2007, 29).

Kachle zobrazující lovená zvířata včetně různých loveckých technik byly rozšířeny nejen v českých zemích, ale i v Polsku a Německu. V historickém jádru Brna byla zjištěna kolekce čtyř kachlů, v níž exemplář z Masarykovy ulice č. 4 zobrazuje lovce zápasícího s medvědem či vlkem a má obdobu ve zlomku z Třebíče (Loskotová 2008a, 67, kat. č. 195; 2010, 108; 2011, 80, obr. $52.3,4)$. Ostatní kusy s jelenem štvaným psem a troubícím sokolníkem, datované do poslední třetiny 15. století, pochází z hrnčiřských pecí Pod Petrovem, Kapucínského náměstí a nároží Dominikánské a Mečové ulice. Další, tentokrát kompletní exemplář se sokolníkem z Pekařské ulice č. 5 se nedochoval (Loskotová 2010, 108-109, obr. 4-6; Mazur 2014, 189, Ryc. 6.1; Měchurová 2016, 15-18, 74-75, obr. 6-7).

Rámcově stejně byly chronologicky vročeny exempláře ze sbírky Národního muzea v Praze, v níž se nachází dva kachle se sokolníky, z nichž jeden je zpodoben jako vládce s královskou korunou na hlavě (nelokalizováno, Buštěhrad: Brych 2004, 110, kat. č. 231-232). Jeho blízká analogie je uložena ve staré sbírce lounského muzea, ale tamní jezdec má místo koruny čapku a na ruce s dravcem nataženu rukavici s visícími provázky (Soukupová-Soukup 2017, 137-138, kat. č. 035). Další pražské fragmenty reprezentuje jezdec se psy na vodítku (Kralovice u Říčan: Brych 2004, 116, kat. č. 253) a pěší lovci ze scény se vztyčeným medvědem, jehož obdoba pochází z premonstrátského kláštera $\mathrm{v}$ Milevsku. $\mathrm{V}$ obou př́ípadech pomohl chybějící část se vztyčeným zvířetem identifikovat kompletní kachel ze Starého Knína (pražský Vyšehrad, nelokalizováno: Brych 2004, 116, kat. č. 251-252; Milevsko a Starý Knín: Jiř́ík-Kypta 2013, 87, kat. č. 53, obr. 51).

Další motivy z Prahy zobrazují psy sápající se na prchající jeleny (nelokalizováno, pražský Vyšehrad, Mukařov u Říčan: Brych 2004, 116, kat. č. 254). Samostatně vyobrazené jeleny pak zastupuje zlomek s hlavou zvířete a řetězem kolem krku, poukazující na odchytávání živé kořisti. Jiné zviŕre má pod krkem zavěšen zvonek, který se používal jako zvuková signalizace př̀ štvanicích (nelokalizováno, Praha - Staré Město, Na Můstku: Brych 2004, 101, kat. č. 208; Brych-Stehlíková-Žegklitz 1990, 30, kat. č. 60). Dvě torza pak zachycují pronásledujícího psa, na větším z nich je vyobrazen sudokopytník se šípem u nohou (Brych-Stehlíková-Žegklitz 1990, 29-30, kat. č. 58-59).

Specifickou skupinu pražských motivů zastupuje vyobrazení jelenů ležících na lesní louce. Jeden z nich má vedle sebe korunu uloženou ve schránce, podobně jako na exempláři z Národního muzea. Tyto kusy se až na drobné odchylky podobají nálezům ze sbírek chrudimského nebo ústeckého muzea (Nové Město nad Metují, hrad Sion: Brych 2004, 102, kat. č. 209-210; Chrudimsko: Frolík 2003, 57, kat. č. 88; Ústí nad Labem - Předmostí: Soukupová-Soukup-Wiesnerová 2017, 138, kat. č. 036). Zvíře mohlo být umístěno i do medailonu, jak to dokládá exempláŕ z hradu Rožnova s jelenem a vlající textilií (šálou), která měla údajně sloužit k orientaci lovců př̀ štvanicích v oborách (hrad Rožnov, Plzeň: Pavlík 1992, 8, č. 5; Kohoutek 2003, 103, č. 5; Pavlík-Vitanovský 2004, 101, 247, č. kat. 611; Orna 2005, 179, tab. 27:4; Loskotová 2008a, 50, č. kat. 134; Holoubková 2013, 28-29, 96, č. 24).

Vedle různě ztvárněných jelenů se $\mathrm{v}$ kolekci z Národního muzea vyskytl také fragment s bachyní, považovanou spolu s medvědem za zvíře nečisté, spojované s d'ábelským pokušením. Výjimečně byl na reliéfních stěnách zachycen zajíc štvaný psem, jak ukazuje mladší zeleně 
glazovaný kachel z počátku 16. století, původně zasazený do kamnové ŕímsy (Stradonice: Brych 2004, 117, kat. č. 257).

Do 15. věku byla vročena také série čtyř loveckých výjevů z hradu Kumburku u Semil, které zobrazují jelena štvaného dvěma psy, s obdobou v exempláři ze Sedlčan. Odsud a ještě z Malé Strany pochází analogie dalšího kumburského kusu se dvěma loveckými psy a psovodem ozbrojeným mečem. Poslední fragment z hradní kolekce zobrazuje jedoucího sokolníka provázeného psem, podobá se kusu z hradu Pecka a z Prahy (Richterová 1982, 47, 315, 317, tab. 57:2, 4; Vařeka 1997, 402, 405, obr. 4:3; Zavřel 1998, 219; Drnovský 2015, 388-389, obr. 4:5, 5:1-5). Dva maličké zlomky s hlavou sokolníka a tělem psa byly identifikovány ještě v lokalitě Ostrov na Písecku, v Ostrovském rybníku (Jiř́ik-Kypta 2013, 85, kat. č. 51-52).

Lovecké scény se sokolníky a štvanými jeleny se poměrně často vyskytují také ve slezské a polské kachlové produkci. Z dolnoslezské Vratislavi jsou známy dva kachle se sokolníky, z nichž jeden je korunován, podobně jako na kachli z Národního muzea (Więzienna ul.: Dymek 1995, 34, tabl. XIb, c); druhý, rohový, pochází z předválečných výzkumů a je doplněn vegetací s kapkovitými listy (Dymek 1995, 284, tabl. LIV3). Klasičtí sokolníci s loveckým rohem a opeřencem na ruce byli doloženi na lokalitách Bielsko (Moskal 2010: 7; 2012: 82, 84), Bodzentyn (Kuczyński 1968, 11, 20), Bolesławiec nad Prosną (Żemigała 1987, 21, tabl. II, ryc. 1), Kobiernice (Tomkiewicz-Indquist 1884, tabl. IV:5) nebo Oświęcim (Chmiel 1906, 347-348, ryc. 6; Moskal 2012, 84-85, kat. 5). Pro jeleny pronásledované psy je charakteristický strnulý postoj, typický pro kachlovou produkci ze severněji položených lokalit Biecz (Ślawski 1994, 218, ryc. 22), Bielsko (Moskal 2010, kat. 7), Hnězdno, stan. 22 (Janiak 2003, 28, 93, il. 137, 177-179, 198), Chęciny (Hadamik 2010, 19, ryc. 3), Jankowo Dolne (Janiak 2003, il. 197), Oświęcim (Moskal 2010, 8, fot. 3b), Raciążek (Kajzer 1990, 205, ilustr. 73:5), Sierakowo (Gajewska 2010, 213), Malbork (Pospieszna 2013, 73) a Gdaňsk (Kilarska 2007, 211, ryc. 158).

Přestože vrcholu obliby dosáhly lovecké motivy ve druhé polovině 15 . století, do kachlové tvorby se vrátily ještě ve věku následujícím. Renesanční ztvárnění přineslo na rozdíl od gotiky oživení strnulých postojů a do scén vneslo větší dynamiku, jak to dokládá sokolník na cválajícím koni pod renesanční arkádou (Chojnów: Dymek 1995, 34, 278, tab. XLV1). K poslednímu znovuoživení lovecké ikonografie došlo ještě na konci 16. a počátku 17. století, kdy jako předlohy posloužily grafické listy Josta Ammana (1539-1591), Antonia Tempestyho (1555-1630) nebo Virgila Solise (1514-1562), podle nichž vznikaly pozdně renesanční a raně barokní reliéfy, nalezené v Gdaňsku, Fromborku, Modliszewicích, Nowém Miastu nebo Tykocině (Samsonowicz 2011, il. 1-46; Pospieszna 2013, 155-159; Szczepanowska 2014, 137-144).

\section{Lovecké kachle z českého Slezska a jejich datování}

Kachle s loveckými výjevy, které se v reliéfní výzdobě objevily ve druhé polovině 15 . století, se vyskytly také v českém Slezsku, a to v souboru nálezů z hradu Cvilína (k. ú. KrnovOpavské předměstí), uloženém v archeologické sbírce Slezského zemského muzea (Pavlík-Vitanovský 2004, 88; Pavlík 2007, 86-87; Tymonová 2009, 216; 2011, 52-53; Loskotová 2010, 108; $2011,79)$. Jde vesměs o režné kusy pocházející nejspíše ze dvou kamnových těles vyzvednutých z nestratifikovaných substrukcí na hradním nádvoří poblíž válcové věže. Další jedinec se štvanicí na jeleny se našel v roce 1912 při kopání základů staré radnice na Horním náměstí v Opavě. Aby se osvětlil původ kolekce, byly z vybraných jedinců odebrány vzorky k petrografické analýze, která naznačila předpokládanou opavskou provenienci (Pavlík-Vitanovský 2004, 88; Tymonová 2009, 192-193; 2011, 39).

Ve cvilínském konvolutu byly identifikovány dva základní motivy, a to sokolníci jedoucí na koni v doprovodu psů (1. skupina) a pak štvaná zvěř $-\mathrm{v}$ tomto př́ípadě scény se samostatně ztvárněnými jeleny (2. skupina). První skupinu prezentuje dvojice téměř shodných motivů se sokolníky držícími roh v pravé a dravce na levé ruce. První varianta s jedním psem na vodicí šňǔře v pravém spodním rohu je doplněna jednoduchými květy a vegetací př́ipomínající fafrnochy nebo vlající textilii (Nekuda-Reichertová 1968, tab. XCIX:3; Michna 1977, 39, obr. 
21; Pavlík-Vitanovský 2004, 246, kat. č. 601; Pavlík 2007, 87, č. XI; Menoušková 2008, 66, kat. č. 190, 192; Tymonová 2009, 214, tab. 3:10; 2011, 52-53; tab. 10:9-10, 23:12-20, 24:1-20, 25:1-10; Mazur 2014, 196, ryc. 6). Jde přibližně o deset až dvanáct kusů vyrobených z jemnější pískem ostřené hlíny vypálené do šedohnědých nebo hnědočervených tónů (obr. 4; vzorek 1 , inv. č. M 680). Druhá varianta se dvěma psy je s předchozím kompozičně shodná, avšak liší se počtem psů umístěných v pravém rohu nad sebou, dále absencí vegetace s kapkovitými lístky a také jemnějším materiálem (Kouřil-Prix-Wihoda 2000, 59, obr. 22; Pavlík-Vitanovský 2004, 246, kat. č. 600; Pavlík 2007, 87, č. XI; Loskotová 2008, 536, obr. 5:3; Menoušková 2008, 66, 58, kat. č. 191, 192). Dochovala se v počtu minimálně osmi až deseti kusů vyrobených z hnědošedé hrubším pískem ostř́ené masy (obr. 5; vzorek 2, inv. č. M 574).

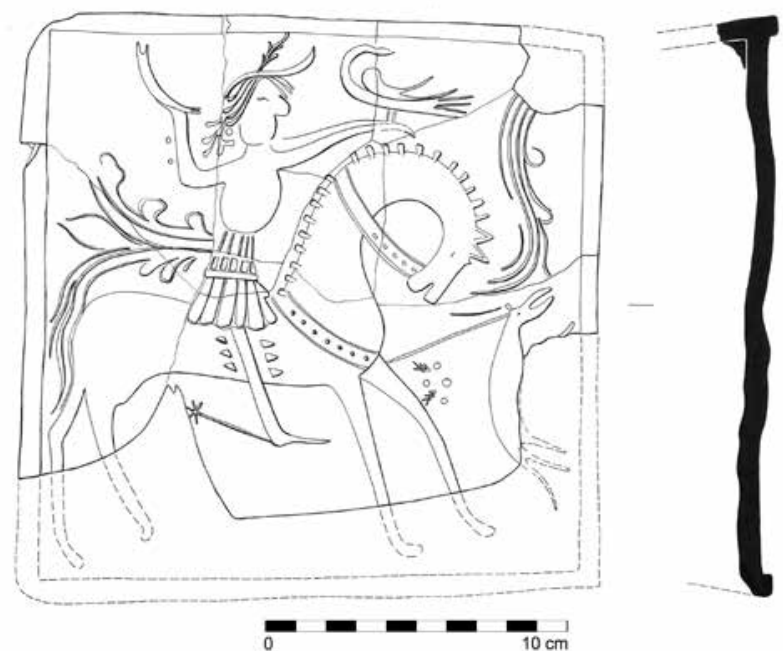

Obr. 4. Hrad Cvilín. Sokolník s jedním psem (vzorek 1). Kresba M. Schindlerová. Abb. 4. Burg Cvilín. Falkner mit einem Hund (Probe 1). Zeichnung M. Schindlerová.

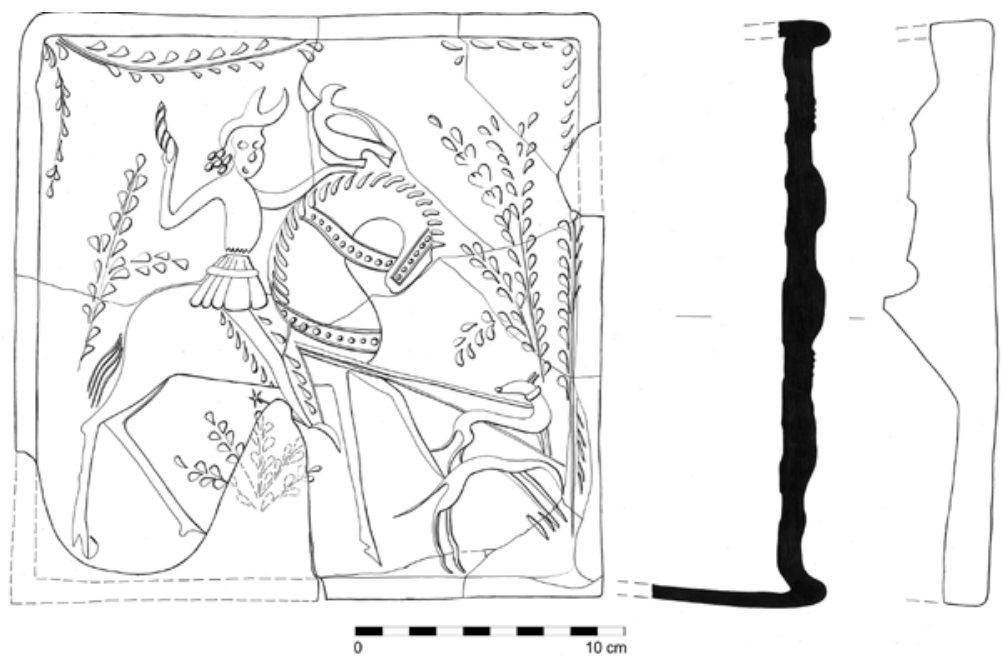

Obr. 5. Hrad Cvilín. Sokolník se dvěma psy (vzorek 2). Kresba M. Schindlerová.

Abb. 5. Burg Cvilín. Falkner mit zwei Hunden (Probe 2). Zeichnung M. Schindlerová. 
Druhou skupinu reprezentují jeleni se psy. První varianta zobrazuje jelena hledícího dopředu s parožím o deseti výsadách a větvičkou v tlamě, jak ho pronásleduje pes (obr. 6; vzorek 3, inv. č. M 544). Scénu doplňuje strom se sedícím opeřencem a keře s kapkovitými listy, jež tvoří doprovodný prvek i v jiných výjevech (Šikulová 1999, 228, kat. č. 124; Kouřil-Prix-Wihoda 2000, 59, obr. 23; Pavlík-Vitanovský 2004, kat. 614 II; Loskotová 2008, 535-536, obr. 5:2; Menoušková 2008, 58, 65, kat. č. 186; Tymonová 2009, 217, tab. 3:1; 2011, 53-54, tab. 10:3-4, 21:14-20, 22:1-10). Jde o fragmenty z přibližně patnácti režných jedinců, z nichž část je vyrobena $\mathrm{z}$ hlíny ostřené hrubým křemitým pískem vypálené do odstínů šedohnědé barvy. Na rubové straně jednoho rekonstruovaného kusu je spirálovitý žlábek po zamačkávání formy, překrytý zčásti sádrováním. Ostatní více či méně dochované fragmenty s toutéž výzdobou byly vyrobeny z jemnější pískem ostřené do červenohněda vypálené keramické masy s prstovitými důlky po zamačkávání do formy na rubové straně čelní vyhřívací stěny (vzorek 4, inv. č. 1954/405). Druhá varianta se zbytkem krouceného provazce na hraně rohového fragmentu zobrazuje jelena hledícího dozadu na strom se sedícím pernatcem (obr. 7; vzorek 5, inv. č. 1954/328). Že šlo o výjev z honitby s podobnou vegetací jako $\mathrm{v}$ předchozím prrípadě, dokládá zubatá psí tlama u předních běhů zvířete (Tymonová 2009, 214, tab. 2:12; 2011, 53-54, tab. 10:3-4, 21:12-20, 22:1-10, 25:11).

Doplňková výzdoba v podobě keřu či stromků s kapkovitými listy spojuje lovecké motivy s galantní scénou (obr. 8; vzorek 6, inv. č. M 681), v níž žena podává muži opeřence (Tymonová 2009, 217, tab. 3:3; 2011, 52-53, tab. 10:10-11, 26:7-18), a rekonstrukcí souboje na meče s dvojicí zápasících mužů (obr. 9; inv. č. 1954/329, 411), jejichž materiál je makroskopicky totožný (Tymonová 2009, 214, tab. 2:7; 2011, 51, tab. 25:12-20, 26:1-5). Na rubové straně obou kusů jsou patrné stopy po uhlazování a zamačkávání hlíny, která byla vypálena do šedohnědé až červenohnědé barvy.

Další kachel s loveckou scénou pochází z opavského Horního náměstí (z prostoru bývalé radnice pod dnešní Slezankou), jehož petrografický rozbor nebyl proveden kvůli nepovolení odběru vzorku (Šikulová 1999, 227, kat. č. 111; Pavlík-Vitanovský 2004, 102, 247, 374, kat. č. 620; Menoušková 2008, 58, 66, kat. č. 193; Tymonová 2009, 214, tab. 2:11; 2011, 52). Kachel má režný povrch šedohnědé barvy a na jeho reliéfní stěně je zpodoben jezdec se sokolem v pravé a otěžemi v levé ruce, který štve dva jeleny za asistence dvojice psů. Scénu doplňují tři stylizované stromy s kuželovitými korunami, jež evokují lesní prostředí (obr. 10; inv. č. M 695).

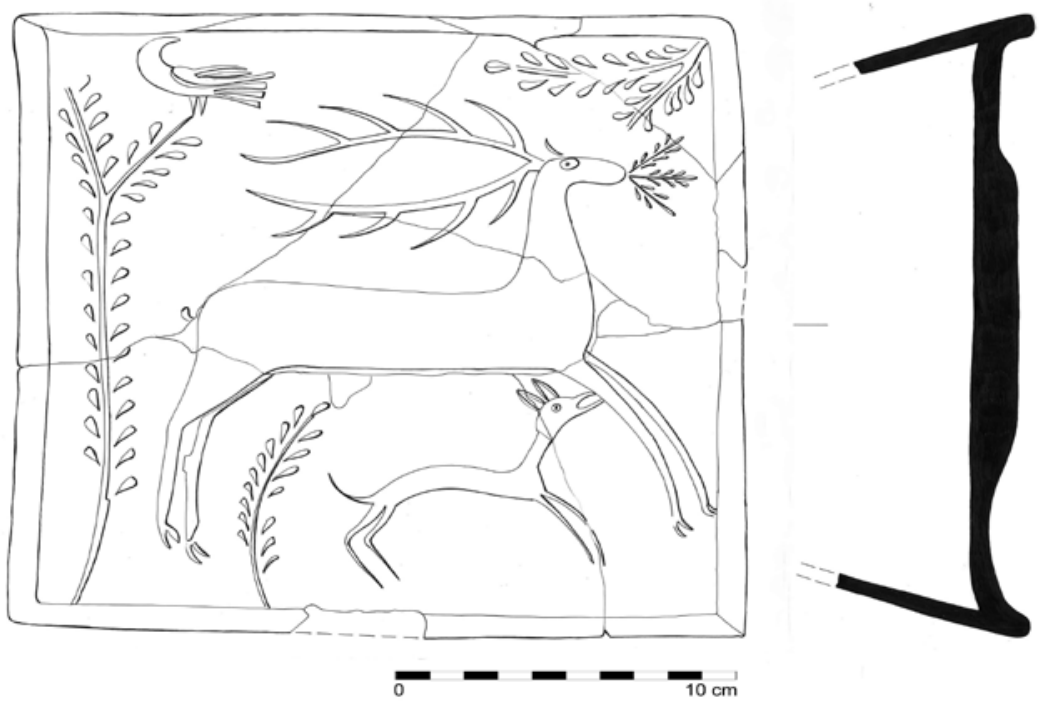

Obr. 6. Hrad Cvilín. Jelen hledící dopředu (vzorek 3). Kresba M. Schindlerová.

Abb. 6. Burg Cvilín. Nach vorne blickender Hirsch (Probe 3). Zeichnung M. Schindlerová. 

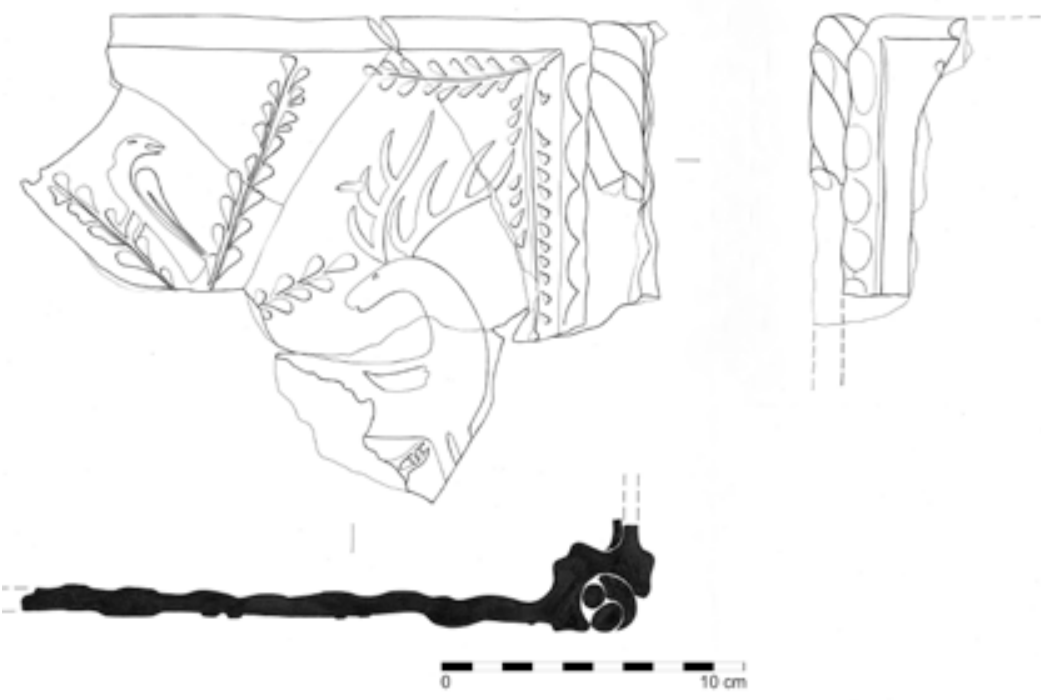

Obr. 7. Hrad Cvilín. Jelen hledící dozadu (vzorek 5). Kresba M. Schindlerová.

Abb. 7. Burg Cvilín. Nach hinten blickender Hirsch (Probe 5). Zeichnung M. Schindlerová.

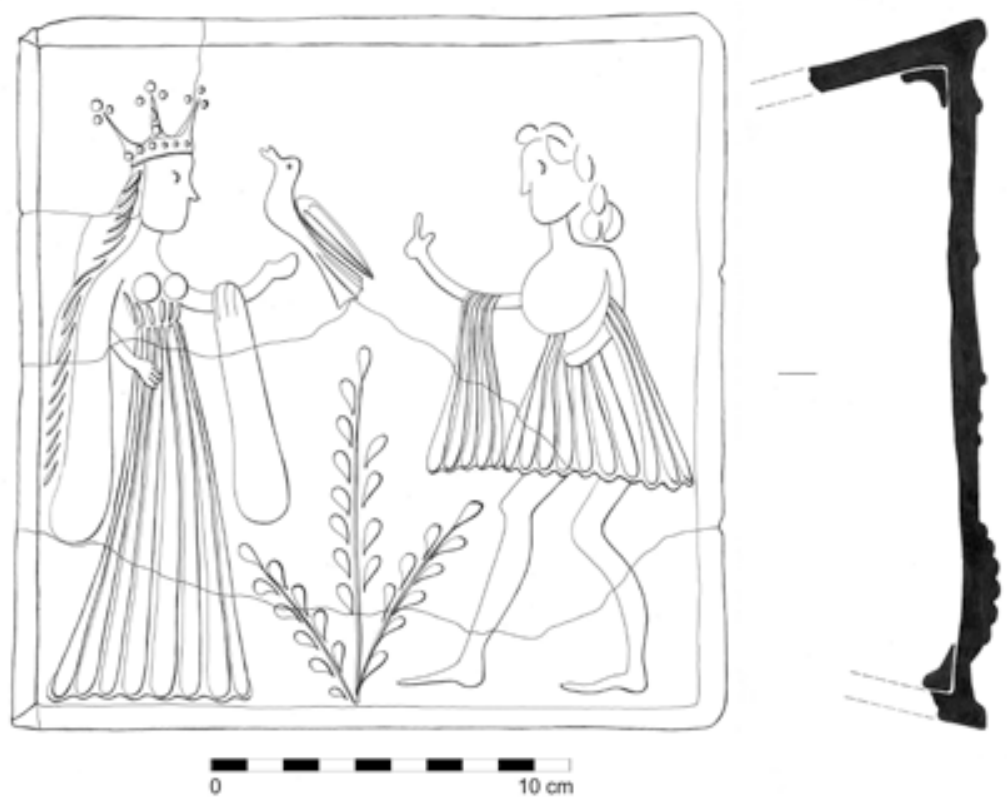

Obr. 8. Hrad Cvilín. Galantní scéna (vzorek 6). Kresba M. Schindlerová.

Abb. 8. Burg Cvilín. Galante Szene (Probe 6). Zeichnung M. Schindlerová.

Nejbližší protějšky ke cvilínským kachlům představují polské exempláře z Ratiboře a Goryczek u Vladislavi (Wodzisław Śląski), které leží v jihozápadní části bývalého ratibořského knížectví ve vzdálenosti přibližně 30 a $50 \mathrm{~km}$ od Opavy. V obou nálezových celcích se nachází také zlomky kachlů s milostnými scénami s odlišnostmi v detailech, $\mathrm{v}$ nichž zahradu lásky supluje keř s kapkovitými lístky (Czechowicz 1993, 19-20; Biel 2013, 50-51, tab. 25b). 


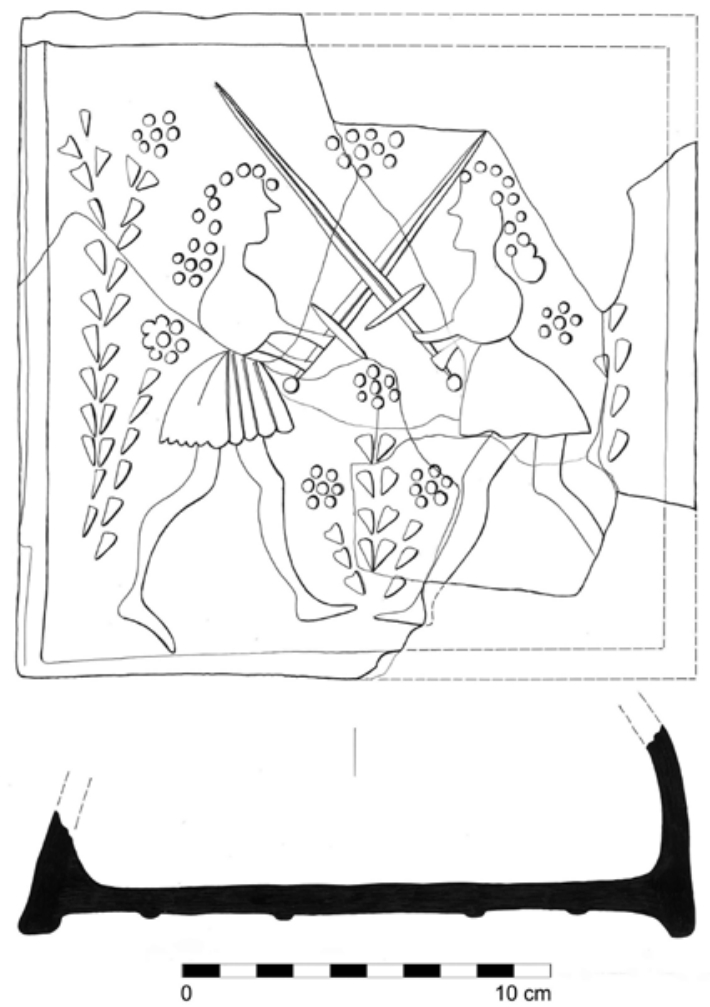

Obr. 9. Hrad Cvilín. Výjev se soubojem na meče. Kresba M. Schindlerová.

Abb. 9. Burg Cvilín. Szene mit Schwertzweikampf. Zeichnung M. Schindlerová.

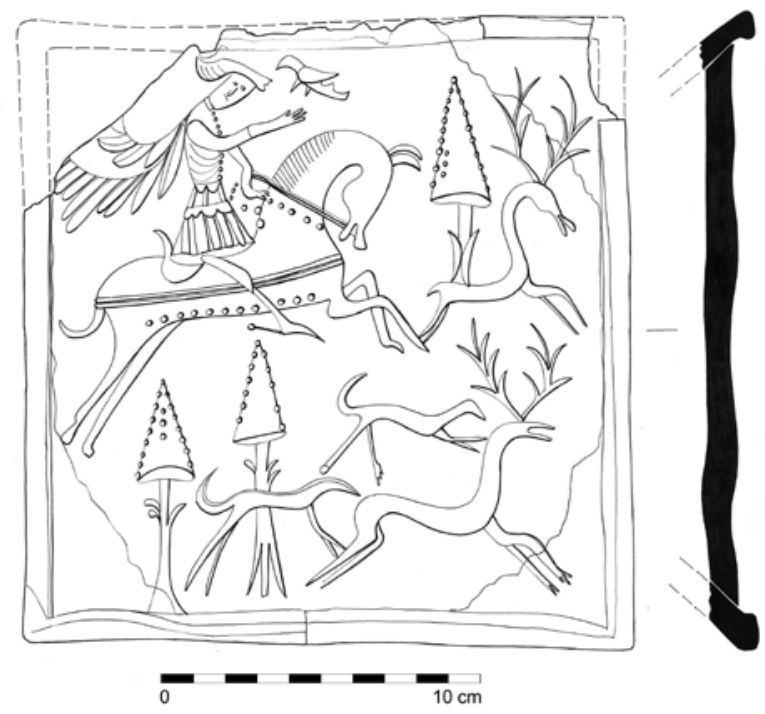

Obr. 10. Opava, Horní náměstí. Štvanice na jelena. Kresba M. Schindlerová.

Abb. 10. Opava, Oberer Markt. Hetzjagd auf einen Hirsch. Zeichnung M. Schindlerová. 
První analogii ke cvilínským kachlům s jelenem reprezentuje hnědě glazovaný fragment, získaný v 80 . letech minulého století během komplexního archeologického výzkumu areálu bývalého piastovského hradu v Ratiboři, se zvířetem hledícím dozadu na postavu, z níž se zachovala pouze ruka držící hůl. Vedle sudokopytníka kráčí pes s obojkem opatřeným velkým záchytným okem. Od cvilínského fragmentu se liší jak povrchovou úpravou, tak i tím, že jelen má v tlamě větvičku s kapkovitými lístky. Další rozdíly se týkají použité suroviny, kterou tvoří jemně plavená, do světle hněda vypálená hlína. I v tomto případě se na rubu čelní stěny zachovala mělká spirála, jež je považována za doklad zamačkávání plátu hlíny do formy položené na desku hrnčírského kruhu (obr. 11; vzorek 7, inv. č. Rz 206/87).

Odlišné složení i výpal charakterizuje rekonstruovaný a sádrou doplněný exemplář se sokolníkem z hrádku Gorzyczki, který nebyl analyzován kvůli možnému poškození při odběru vzorku (obr. 12). Kachel byl vyroben z hnědě až rezavě vypálené železité hlíny, a přestože ikonograficky připomíná kus s jedním psem, vyznačuje se několika odlišnostmi: pes běží vedle koně, resp. pod koněm, a lesní roh lovec přidržuje nikoli pravou, ale levou rukou; na druhé sedí opeřenec. V nálezovém souboru získaném během výkopů mezi lety 1969-1976 se kromě jiného zlomku se spodní částí galantní scény nachází i fragment s Beránkem Božím, pod nímž je umístěn charakteristický keř s kapkovitými lístky. Jde o ztvárnění velmi podobné kusům ze Cvilína, a proto je zřejmé, že tvůrce formy evidentně vycházel z podobné předlohy (Biel 2013, $50-51$, ryc. $25 \mathrm{a}, \mathrm{b})$.

Vegetace s drobnými lístky představuje jednotící prvek skupiny žánrových reliéfů, do níž spadají nejen pronásledovaní jeleni nebo sokolníci (Bulhary, Kloboucko: Pavlík 2007, 86-87; Třebíč: Nekuda-Reichertová 1968, 393, tab. LXXXVIII; Vratislav: Dymek 1995, tabl. LIV:3; Loskotová 2011, 99, obr. 68:9), ale vyskytuje se i v dalších motivech, a to charakteru profánního (hrnčíř z Landštejna: Pavlík-Vitanovský 2004, 262, kat. č. 779; Nekuda-Reichertová 1968, 393, tab. LXXXVIII; sedící královna v zahradě lásky - hrad/zámek Vleń: Dymek 1995, 33, 256, tabl. XIXa), náboženského (Zmrtvýchvstání z Lipska, Žitavy a Brna - Kapucínského náměstí: Strauss 1966, 11, T 4.3; 1983, T 9.1; Pavlík 2008, 25, kat. č. 51; sv. Martin z hradu Jawor: Pavlík-Vitanovský 2009, 249, obr. 7; sv. Jiří z Vratislavi: Dymek 1995, tabl. LIV:4) a alegorického (divý muž z Neuzelle: Strauss 1983, 15-16, T 25.5; sv. Václav z Brna - Kobližné ulice: Stehlíková
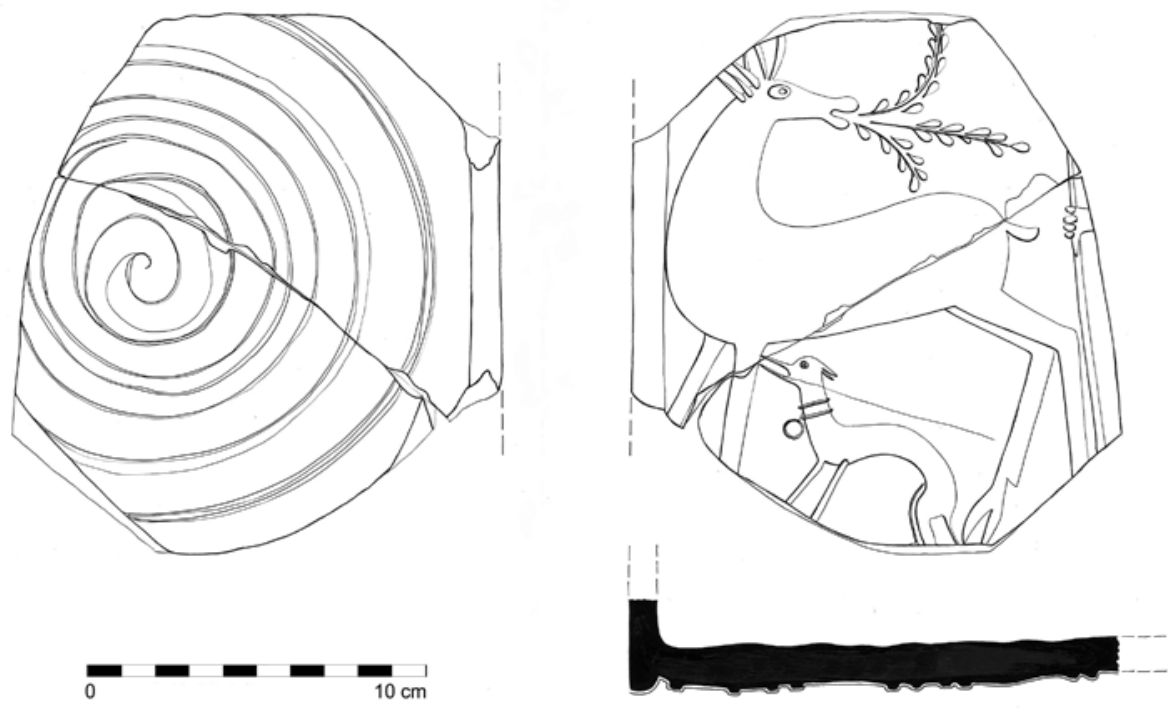

Obr. 11. Ratiboř, Piastovský hrad. Jelen hledící dozadu (vzorek 7) . Kresba M. Schindlerová.

Abb. 11. Ratibor, Piastenburg. Nach hinten blickender Hirsch (Probe 7). Zeichnung M. Schindlerová. 


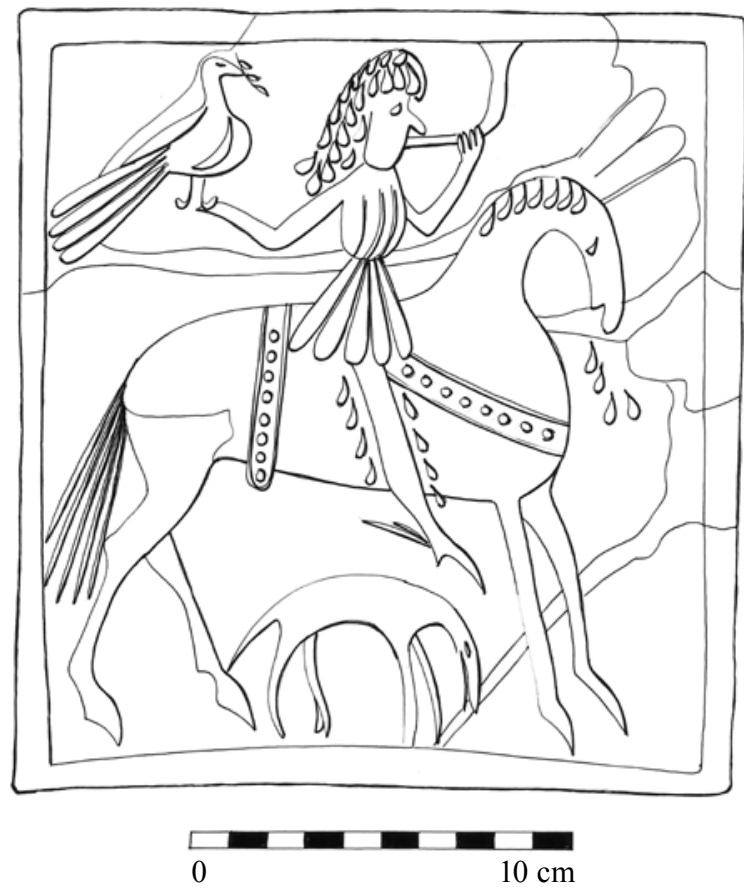

Obr. 12. Gorzyczki u Vladislavi. Sokolník s jedním psem. Kresba M. Schindlerová.

Abb. 12. Gorzyczki bei Wodzisław Śląski. Falkner mit einem Hund. Zeichnung M. Schindlerová.

1999, 227, kat. č. 121; Pavlík 2008, 25, kat. č. 51). Jako doplňková výzdoba se tento prvek vyskytuje v reliéfech kachlů rozšiřených v německém Sasku a Lužici, polském i českém Slezsku a také v Čechách a na Moravě (Loskotová 2008, 535-536; 2011, 26, 42-43, 98-99).

Datování sledovaných exemplářů lze vzhledem $\mathrm{k}$ výskytu kachlů s loveckou tematikou položit rámcově do druhé poloviny 15 . století až do období kolem roku 1500 . V případě kachlů ze Cvilína by objednatelem mohl být opavský kníže, protože krnovské zboží převzal v roce 1437 Mikuláš V. († 1452), který z hradu učinil rezidenční sídlo. Za jeho syna Jana IV. († 1483), jenž od roku 1456 připojil také Krnov a Vladislav, byl v roce 1474 dobyt vojsky Matyáše Korvína a poté byl opravován. K loveckým účelům však mohl sloužit i za Šelmberků v letech 1493-1523, kteří v období let 1502-1517 drželi také vladislavské zboží, které v roce 1502 Janu z Šelmberka daroval Vladislav Jagellonský. V roce 1524 koupil krnovské knížectví Jiří Braniborsko-Ansbašský, jenž díky spř́iznění s panovníkem působil na budínském dvoře jako vychovatel kralevice Ludvíka († 1526). Když získal majetky na Krnovsku, nechal hrad vybavit novými kamny vyrobenými evidentně podle uherských vzorů. Na základě tohoto krátkého exkurzu však nelze spolehlivě rozhodnout, zda objednatelem loveckých kamen byl opavský kníže (Mikuláš V. či Jan IV.), nebo Šelmberkové. Je však zřejmé, že jejich vznik spadá do poslední třetiny 15 . století, případně do doby okolo roku 1500 (Prix 1994, 44; Kouřil-Prix-Wihoda 2000, 461, 472, 476, 485; Fukala 1998, 137; Furmanek-Kulpa 2003, 27-30, obr. 38; Tymonová 2011, 35-37; Biel 2013, 11).

Více světla do určení původu lovecké kolekce vnesly mikropetrografické rozbory, které naznačily dřívější předpoklad, že kachle mohly být vyrobeny v Opavě, kde v letech 1965 a 2007 byla doložena hrnčířská dílna v Krnovské ulici. V jejím inventáři se sice analogické nálezy s loveckou tematikou nevyskytly, zato byla doložena podobnost s místními zdroji hlín (Tymonová 2014, 165). 


\section{Mikropetrografické rozbory kachlů}

Z představené lovecké kolekce bylo analyzováno celkem sedm vzorků, z nichž šest bylo odebráno ze cvilínských nálezů (vzorky 1-6) a jeden z kachle zapůjčeného z Ratiboře (vzorek 7). Kolekce byla podrobena mikropetrografickým rozborům, které měly především určit, zda jsou kachle vyrobeny z lokálních keramických surovin a zda lze vypozorovat surovinovou spojitost mezi jednotlivými vzorky (Gregerová et al. 2010, 34). Z vybraných vzorků byly zhotoveny výbrusové preparáty, které byly studovány pomocí polarizačního mikroskopu Olympus BX 51. U každého vzorku bylo stanoveno zastoupení úlomků minerálů a hornin, na základě barevných změn minerálů byla stanovena teplota výpalu kachlů. U vzorků 1-6 ze Cvilína pozorujeme mezi jednotlivými exempláŕi téměř úplnou materiálovou shodu. $\mathrm{Z}$ minerálů identifikujeme v keramické hmotě křemen, draselné živce plagioklasy (převažují nad alkalickými živci), akcesoricky je přítomen muskovit a biotit. $Z$ úlomků hornin se ve cvilínských kachlích nejčastěji setkáváme s úlomky sedimentárních hornin: droby, křemence, prachovce, jílové hrudky, bročky a hrudky Fe-oxyhydroxidů. Z metamorfovaných hornin byly identifikovány kataklazity, biotit-muskovitové až muskovitové břidlice a metakvarcity. $Z$ magmatických hornin lze rozpoznat pouze aplity. Dalším specifikem tohoto souboru jsou mikroskopicky pozorovatelné černé, kulaté nebo protáhlé okrouhlé částice v pórech, které by mohly odpovídat zuhelnatělé organické hmotě (např. jemným pilinám). Kachle byly zhotoveny z cihlářské hlíny a tvrdě vypáleny při teplotách kolem $1000{ }^{\circ} \mathrm{C}$. Jednotlivé kachle se mezi sebou odlišují pouze $\mathrm{v}$ procentuálních poměrech ostřiva, pojiva a pórů. Předpokládáme, že keramická surovina pro výrobu kachlů byla natěžena z náplav řeky Opavy. Naproti tomu vzorek kachle z Ratiboře (vzorek 7; inv. č. RZ 206/87) je materiálově naprosto odlišný. Ve výbrusovém preparátu z minerálů pozorujeme křemen, který výrazně převažuje nad alkalickými živci a plagioklasy, akcesoricky jsou zastoupeny biotit a muskovit. $\mathrm{Z}$ úlomků hornin převažují úlomky, které jsou bohaté na křemen (křemence, metakvarcity a silicity). Součástí suroviny byly i bročky a hrudky Fe-oxyhydroxidů, které jsou makroskopicky pozorovatelné v hmotě kachle. Teplota výpalu oproti cvilínským exemplářủ je nižší, mohla dosahovat maximálně $900{ }^{\circ} \mathrm{C}$ (obr. 13). Surovinu lze charakterizovat jako cihlářskou hlínu místního původu.

\section{Závěr}

Zpracování předložené stati sledovalo dva cíle. První spočíval v představení kachlů s loveckými motivy ve společensko-historických a sociálních souvislostech prokazujících elitní význam lovu především v rovině společenské. Pojednání této atraktivní aktivity prostřednictvím děl výtvarného umění plně odráží dobovou mentalitu manifestovanou dvorskou kulturou. V př́padě kachlové tvorby, jež na tento fenomén zareagovala během 15. století, nejde o pouhé zobrazení atraktivního námětu, nýbrž současně o vizualizaci ideového poselství vyjádřeného skrze symbolické pojetí lovu a zvířat s ním spojených. Rozšíření kamen v různých sociálních prostředích (panská sídla, města a kláštery) potvrzuje výpověd' písemných a ikonografických pramenů v tom smyslu, že vedle urozených se lovectví věnovaly i osoby duchovního stavu a také měšt’anstvo. Dokládají to i nálezy z českého Slezska, kde byly kachle s loveckými motivy zjištěny v centru Opavy a pak v inventáři asi 20 kilometrů vzdáleného hradu Cvilína, v němž se vyskytly další exempláře se scénami z okruhu dvorských výjevů. Podobně tomu bylo i v nedaleké Ratiboři nebo Gorzyczkách a na dalších lokalitách v českých zemích, Polsku i Německu.

Druhý úkol se zaměřil na zjištění provenience cvilínských kachlů, jejichž hypotetickým objednatelem by vzhledem k délce životnosti kamen (maximálně 20-30 let) a za předpokladu odstranění kolem roku 1524 byl nejspíše některý ze Šelmberků, kteří získali krnovské léno v roce 1493 a do roku 1517 drželi i vladislavské panství. V návaznosti na vročení loveckých kachlů do druhé poloviny, či úžeji do poslední třetiny 15 . století není vyloučeno, že objednatelem mohl být opavský kníže, jenž spolu s Krnovskem spravoval i sousední Ratibořsko. 

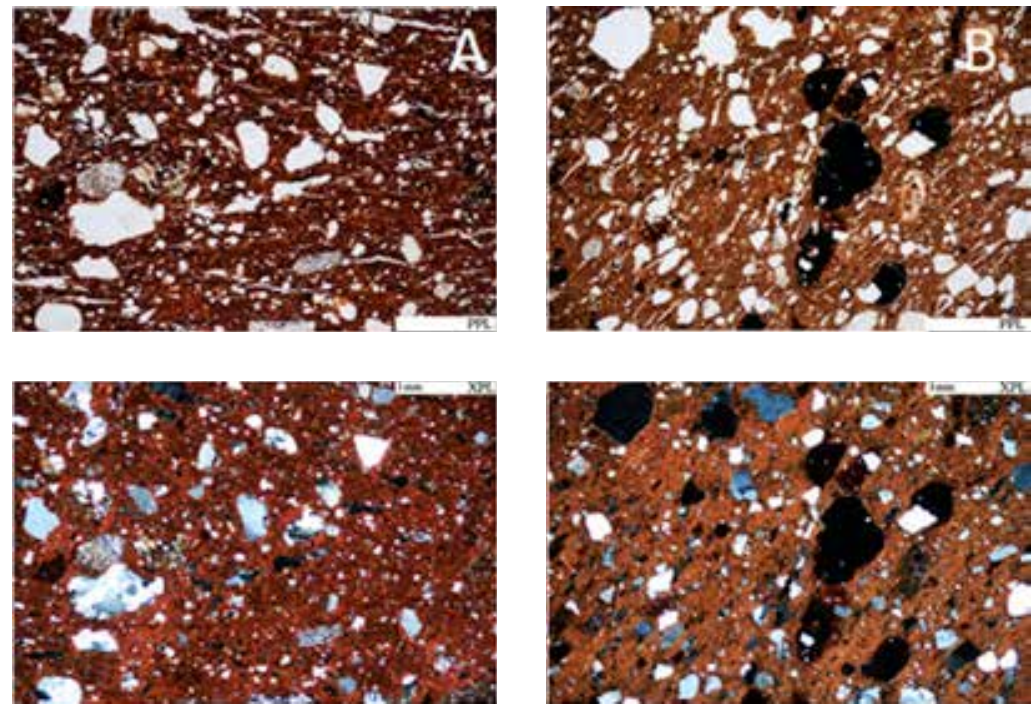

Obr. 13. Celkový pohled na mikrostruktury kachlů. Mikrofotografie A - charakteristická mikrostruktura cvilínských kachlů na př́íkladu vzorku M 680, který obsahuje polozaoblené úlomky drob, křemenců, prachovců aj. Mikrofotografie B - ukázka odlišnosti mikrostruktury vzorku kachle z Ratiboře, kde převažují zaoblené hrudky Fe-oxyhydroxidů. Petrografický mikroskop Olympus BX 51, horní snímek v procházejícím světle mikroskopu (PPL) a dolní snímek př̀i zkř́ižených nikolech (XPL).

Abb. 13. Gesamtansicht der Mikrostrukturen der Kacheln. Mikrofotografie A - charakteristische Mikrostruktur der Kacheln von Burg Cvilín am Beispiel von Probe M 680, die halbabgerundete Bruchstücke von Grauwacken, Quarziten, Schluffsteinen u.a. enthält. Mikrofotografie B - Beispiel für die unterschiedliche Mikrostruktur der Probe von der Kachel aus Ratibor, wo abgerundete Klümpchen von Fe-Oxyhydroxiden überwiegen. Petrografisches Mikroskop Olympus BX 51, obere Aufnahme im Durchlichtmikroskop (PPL) und untere Aufnahme bei gekreuzten Polarisatoren (XPL).

Podle výsledků mineralogicko-petrografických analýz byla k výrobě sledovaných kachlů použita surovina opavského původu, což vylučuje dovoz z větší vzdálenosti. Vzhledem $\mathrm{k}$ tomu, že kamnářská výroba byla na Opavsku doložena pouze v Opavě, za místo vzniku lze pokládat nejspíše dílnu v Krnovské ulici, v níž se kachlové zboží vyrábělo až do počátku třicetileté války. Pro kachle s loveckými motivy však tento závěr platí pouze hypoteticky, protože v souborech indikujících kamnářskou činnost jednoznačnou oporu nemáme. Jediný exemplář se štvanicí z Horního náměstí, jejž se nepodařilo analyzovat, dokládá pouze vytápění některého z měštanských př́ibytků. Distribuci z místní dílny však nepřímo naznačují kachle s trůnící P. Marií nebo fragmenty orámované sukovatkou, známé jak ze Cvilína, tak i z Opavy - Kolářské ulice č. 13 (Krasnokutská 2005, 28-29, 108-109, Tab. 16:1, 2; Tab. 17:1-8; Tymonová 2011, 46). Navzdory těmto indiciím zůstává otázka místa výroby sledovaných kamnářských výrobků nadále otevřená a čeká na nové nálezy, které by předložené závěry jednoznačně potvrdily.

Příspěvek vznikl s podporou grantového projektu GA17-13967S Zdroje a šiření vybraných komodit keramické produkce vrcholného a pozdního středověku.

\section{Prameny a literatura}

ANDRESKA, J.-ANDRESKOVÁ, E., 1993: Tisíc let myslivosti. Vimperk.

BERANOVÁ, M., 2000: Slované. Praha.

BEZDĚK, F., 2001: Cesty a osudy loveckého rohu. Kostelec nad Černými lesy. 
BIEL, R., 2013: Rycerze, święci i potwory, czyli opracowanie materiałów z gródka stożkowatego w Gorzyczkach. Rkp. nepubl. magisterské práce Instytutu Archeologii Uniwersytetu Wrocławskiego, ved. práce Prof. dr. hab. K. Wachowski, Wrocław.

BIELICHOVÁ, Z.-LABUDA, J., 2017: Nálezy zvieracích kostí z výskumu Glanzenbergu tzv. Starého mesta v Banskej Štiavnici, Zborník Slovenského banského múzea XXV, 30-69.

BOGACKI, M., 2003: Sokolnictwo na terenach ziem Polski od wczesnego średniowiecza do nowożytności (IX-XVIII wiek). Rkp. magisterské práce Instytutu Archeologii Uniwersytetu Warszawskiego, ved. práce Prof. dr. hab. A. Lasota-Moskalewska, Warszawa.

BOHÁČEK, I., 2011: Lesy a hvozdy, Vesmír 90, č. 10, 539.

BORETIUS, A., ed., 1883: Capitulare de villis. In: Monumenta Germaniae Historica. Legum sectio II. Capitularia regum Francorum. Tomus I., 83-91. Hannover.

BRYCH, V., 2004: Kachle doby gotické, renesanční a raně barokní. Výběrový katalog Národního muzea v Praze. Praha.

BRYCH, V.-STEHLÍKOVÁ, D.-ŽEGKLITZ, J., 1990: Pražské kachle doby gotické a renesanční. Katalog výstavy. Praha.

BƯŽEK, V.-HRDLIČKA, J.-KRÁL, P.-VYBÍRAL, Z., 2002: Věk urozených. Šlechta v českých zemích na prahu novověku. Praha - Litomyšl.

CZECHOWICZ, B., 1993: Późnogotyckie kafle z zamku w Raciborzu, Śląskie Zeszyty Krajoznawcze, IK $66,18-25$.

ČAPSKÝ, M., 2005: Vévoda Přemek Opavský (1366-1433). Ve službách posledních Lucemburků. Olomouc - Opava.

- 2006: Proměny dvorské elity jako odraz poklesu prestiže opavských Přemyslovců. In: Dvory a rezidence ve středověku (Dvořáčková-Malá, D., ed.), 123-144. Praha.

- 2009: Lov a jeho role na dvorech slezských knížat - Hunt and its Role at the Courts of the Silesian Dukes. In: Dvory a rezidence ve středověku III. Mediaevalia historica Bohemica 12 - Supplementum 3, 207-222. Praha.

- 2013: Středověká Opava a její zásobování dřevem - Medieval Opava and its wood supply, ČSZM B 62, 107-113.

- 2014: Jagd als Privileg, höfisches Vergnügen und Pflicht. Jagdforste schlesischer Fürsten während des Hoch- und Spätmittelalters. In: Krivoklát-Pürglitz. Jagd, Wald, Herrscherrepräsentation (Fajt, J.Horsch, M.-Razím, V., edd.), 275-288. Leipzig.

ČAPSKÝ, M.-PRIX, D., 2012: Slezsko v pozdním středověku. In: Jirásek, Z. a kol., Slezsko v dějinách českého státu I. (od pravěku do roku 1490), 262-560. Praha.

DEKAN, J., 1980: Moravia Magna. The great Moravian Empire. Its art and times. Bratislava.

- 1979: Vel'ká Morava, doba a umenie. Bratislava.

DRNOVSKÝ, P., 2015: Pozoruhodný soubor kachlů z hradu Kumburku, okr. Semily - A remarkable collection of stove tiles from Kumburk castle, Semily district, ASČ 19, 379-410.

DURDÍK, T., 1988: Výzkum manského domu na Křivoklátě (Předběžné sdělení) - Erforschung des Lehensmannshauses in Křivoklát (Vorbericht), AH 13, 285-298.

- 1997: Encyklopedie českých hradů. Praha.

- 2010: Několik poznámek k české hradní každodennosti - Einige Anmerkungen zum böhmischen Burgalltag, AH 35, 45-62.

DUŠEK, J., 1995: Kůň ve službách člověka. Jílové u Prahy.

DVOŘÁČKOVÁ-MALÁ, D.-ZELENKA, J., 2011: Curia ducis, curia regis. Panovnický dvůr za vlády Přemyslovců. Praha.

DVOŘÁKOVÁ, D., ed., 2007: Kôň a človek v stredoveku. K spolužitiu človeka a koňa v Uhorskom královstve. Budmerice.

DYMEK, K., 1995: Średniowieczne i renesansowe kafle śląskie. Wrocław.

EBERL, A. L., 2015: Die Bedeutung der Falkenjagd für das Hofleben im Mittelalter, Historia scribere 7 , 223-236.

ERGERT, B. E., 2004: Lov v proměnách doby. In: Lov. Historie, zbraně, zvěř (Bluchel, K. G., ed.), 64-131. Praha.

FARKAŠ, Z., 2013: Železné hroty šípov zo svahov Devínskej Kobyly v Bratislave - Eiserne Geschossspitzen aus den Hängen von Devínska kobyla in Bratislava, ZbSNM CVI - Archeológia, 155-160.

FRIED, J., 1997: Kaiser Friedrich II. als Jäger. In: Jagd und höfische Kultur im Mittealter (Rösener, W., ed.), 149-166. Göttingen.

FROLÍK, J., 2003: Kachle Chrudimska. Sbírky Regionálního muzea v Chrudimi. Chrudim. 
FUKALA, R., 1998: Ze Šelmberka. In: Bibliografický slovník Slezska a severní Moravy 11 (Dokoupil, L.Myška, M., edd.), 136-137. Ostrava.

FURMANEK, M.-KULPA, S., 2003: Zamek Wodzisławi i jego właściciele. Wodzisław Śląski.

GAJEWSKA, B., 2010: Piece kaflowe w obiektach muzealnych na terenie Wielkopolski. In: Piece kaflowe w zbiorach muzealnych w Polsce (Dąbrowska, M.-Semków, J.-Wojnowska, W., edd.), 203-220. Frombork.

GALUŠKA, L., 2002: Terčík s motivem jezdce (sokolníka). In: Střed Evropy okolo roku 1000. Eseje a katalog, 452. Praha.

- 2004: Slované. Doteky předků. Brno.

GREGEROVÁ, M. et al., 2010: Gregerová, M.-Čopjaková, R.-Beránková, V.-Bibr, P.-Goš, V.-Hanuláková, D.-Hložek, M.-Holubová-Závodná, B.-Kristová, L.-Kuljovská, Z. Macháček, J.-Mazuch, M.-Procházka, R.-Škoda, R.-Všianský, D., Petroarcheologie keramiky v historické minulosti Moravy a Slezska. Brno.

GUERREAU, A., 2002: Lov. In: Encyklopedie středověku (Le Goff, J.-Schmitt, J.-C., edd.), 368-377. Praha.

HADAMIK, C., 2010: Zbiór fragmentów kafli średniowiecznych i nowożytnych z badań zamku w Chęcinach, woj. Świętokrzyskie - A collection of medieval and moderns tile fragments from the research of the castle Chęciny, Acta Universitatis Lodziensis, Folia archaeologica 27, 11-31.

HADRAVOVÁ, A., 2008: Kniha dvacatera umění mistra Pavla Žídka. Praha.

HÉDL, R.-SZABÓ, P.-RIEDL, V.-KOPECKÝ, M., 2011: Tradiční lesní hospodaření ve střední Evropě I. Formy a podoby, Živa 2, 61-63.

HOLOUBKOVÁ, T., 2013: Gotické a renesanční kachle z hradu Rožnova. Rkp. nepubl. bakalářské diplomové práce na Katedře dějin umění FF UP v Olomouci, ved. práce Mgr. Petr Čehovský, Ph.D., Olomouc.

HORNA, R., 1922: K dějinám moravských úředníků. Díl 1. Praha.

HUDÁČEK, P., 2014: Silva ad pasturam porcorum: Lesné pasenie svín̆ na královských majetkoch v ranostredovekej Európe - Silva ad pasturam porcorum: Forest-pastures of swine at royal estates in Early Medieval Europe, HŠ 48, 71-102.

CHADT, J. E., 1907: Lesní poplatky (dávky). Písek.

CHADT-ŠEVĚTÍNSKÝ, J. E., 1908: Dějiny lovu a lovectví. Louny.

CHMIEL, A., 1906: Kafle średniowieczne znalezione w Oświęcimiu. Teka Grona Konserwatorów Galicji Zachodniej II, 343-353.

IVANIČ, P., 2011: Západní Slovania v ranom stredoveku. História - Kultúra - Hospodárstvo - Náboženstvo. Nitra.

JAN, L., 2000: Úřad lovčího ve 13. a na počátku 14. století. In: Vznik zemského soudu a správa středověké Moravy, 192-208. Brno.

JANIAK, T., 2003: Kafle gotyckie w zbiorach Muzeum Początków Państwa Polskiego w Gnieźnie. Gniezno.

JANIŠOVÁ, J., 2014: Právní úprava myslivosti v moravském zemském právu v 16. a na počátku 17. století Hunting Legislation in the Moravian Land Order in the 16th and early 17th centuries, HŠ 48, $103-111$.

JANIŠOVÁ, J.-JANIŠ, D., 2015: Lov a ochrana zvěře v ustanoveních českého a moravského zemského práva. In: Človek a svet zvierat v stredoveku (Dvořáková, D. a kol., edd.), 409-431. Bratislava.

JEŽEK, M., 1999: Sídelní pás u středověkého Zbečna, Mediaevalia archaeologica 1, 269-304.

- 2012: Dva životy vsi v přemyslovském loveckém hvozdu. Bratronice v raném středověku - Two Lives of a village located in a Přemyslid hunting forest. Bratronice in the Early Middle Ages, Historická geografie 38, č. 2, 239-251.

JIŘÍK, J.-KYPTA, J., edd., 2013: Gotické kamnové kachle na Písecku. Výběrový katalog výstavy Obrazový svět pozdního středověku. Písek.

KAJZER, L., 1990: Zamek w Raciążku. Budownictwo obronno-rezydencjonalne Kujaw i Ziemi Dobrzyńskiej. Łódź.

KILARSKA, E., 2007: Ceramic stove tiles and tile stoves in Gdańsk before 1700. In: Pots and Princes. Ceramic vessels and stove tiles from 1400-1700 (Majantie, K., ed.), 137-141. Turku.

KLÁPŠTĚ, J., 2005: Proměna českých zemí ve středověku. Praha.

KOHOUTEK, J., 2003: Hrady v oblasti Vizovické vrchoviny. Pozdně středověké kachle z hradu Rožnova Burgen in der Region des Vizovicer Hügellandes. Spätmittelalterliche Kacheln aus der Burg Rožnov, Pravěk NŘ - Supplementum 12, 89-110.

KOUŘIL, P.-PRIX, D.-WIHODA, M., 2000: Hrady českého Slezska. Brno - Opava.

KOVAŘÍK, J., 1989: Zmínky o lovu a zvěři ve starých českých písemnostech a písemnictví. In: Myslivecký kalendář 1989, 102-108.

- 1993: Tradice v myslivosti. Dějiny, zvyky, významy, kultura. Praha. 
KOZÁK, P., 2009: „Citharedo cum cane saltante ad mandata domini principis dedi...“Všední den na dvoře hlohovského a opavského vévody Zikmunda Jagellonského - "Citharedo cum cane saltante ad mandata domini principis dedi...” Everyday life at the court of Sigismund Jagiello of Poland and Duke of Głogów and Opava (Troppau). In: Dvory a rezidence ve středověku. III. Všední a sváteční život na středověkých dvorech (Dvořáčková-Malá, M., ed.), 223-239. Praha.

KRASNOKUTSKÁ, T., 2005: Středověké a novověké kachle z Opavy. Katalog nálezů z archeologických výzkumů. Archaeologiae regionalis Fontes 8. Olomouc.

KREJČÍ, K., 2007: Lovecký soud hradu Buchlova. Rkp. rigorózní práce Katedry dějin státu a práva Právnické fakulty MU v Brně.

KRIVJANSKÝ, T., 2007: Sokoliarstvo. 1. diel. História sokoliarstva. Žilina.

KUCZYŃSKI, J., 1968: Kafle z XIV-XVI w. w zbiorach Muzeum Świętokrzyskiego. Katalog wystawy. Kielce.

KYSELÝ, R., 2005: Archeologické doklady divokých savců na území ČR v období od neolitu po novověk Archaeological evidence of wild mammals in the Czech Republic from the Neolithic to the Modern times, Lynx 36, 55-101.

- 2005a: Historie savců od mladší doby kamenné po 17. století ve světle archeozoologických nálezů, Živa 53 , č. $2,85-88$.

- 2015: Historie chovu domácích zvířat v Čechách a na Moravě ve světle archeozoologických nálezů, Živa 63 , č. 5, 225-229.

LEIENDECKER, U., 2004: Lovec a lovený. In: Lov. Historie, zbraně, zvěř (Blüchel, G. K., ed.), 10-63. Praha.

LOSKOTOVÁ, I., 2008: Rostlinné motivy reliéfních kachlů středověkého Brna - Pflanzenmotive auf Brünner mittelalterlichen Reliefkacheln, AH 33, 529-538.

- 2008a: Žánrové motivy. In: Krása, která hřeje. Výběrový katalog gotických a renesančních kachlů Moravy a Slezska - Schönheit, die wärmt. Gotische und renessainzeitliche Kacheln aus Mähren und Schlesien (Menoušková, D.-Měřínský, Z., edd.), 56-71. Uherské Hradiště.

- 2010: Neznámé kachlové reliéfy brněnského Velkého špalíčku - Previously unknown tile reliefs from Velký Špalíček, Brno, Acta Musei Moraviae - Scientiae sociales XCV, 105-112.

- 2011: Brněnské kamnové kachle období gotiky - Brno Stove Tiles in the Gothic Period. Rkp. nepubl. disertační práce na ÚAM FF MU, vedoucí práce doc. PhDr. R. Krajíc, CSc., Brno.

LYSÁ, Ž., 2014: Sokoliarstvo v stredovekom uhorsku. Úvod do problematiky - Die Falknerei in mittelalterlichen Ungarn. Einleitung in die Problematik, HŠ 48, 113-124.

- 2015: O umení lovu s dravými vtákmi. In: Člověk a svet zvierat v stredoveku (Dvořáková, D. a kol., edd.), 432-446. Bratislava.

MACEK, J., 2001: Jagellonský věk v českých zemích 3, 4. Praha.

MATOLÍNOVÁ, B., 2007: Zobrazení dvorské kultury pomocí zvířecí symboliky ve francouzských středověkých rukopisech. Rkp. nepubl. bakalářské práce Fakulty humanitních studií UK, ved. práce PhDr. Blanka Altová, Praha.

MAZUR, D., 2014: Kafle piecowe jako źródło materialne i ikonograficzne. Znaczenie kafli w rekonstrukcji materialnych i niematerialnych aspektów życia codziennego dawnych społeczeństw - Ofenkacheln als materielle und okonographische Quelle. Die Bedeutung von Kacheln bei der Rekontruktion von materiellen und immateriellen Aspekten des Alltags vergangener Gesellschaften, AH 39, 177-203.

MENOUŠKOVÁ, D., 2008: Fantaskní, mytologické a alegorické motivy. In: Krása, která hřeje. Výběrový katalog gotických a renesančních kachlů Moravy a Slezska - Schönheit, die wärmt. Gotische und renaissancezeitliche Kacheln aus Mähren und Schlesien (Menoušková, D.-Měřínský, Z., edd.), 38-55. Uherské Hradiště.

MĚCHUROVÁ, Z., 2016: Chvála středověké každodennosti: Pohled do archeologických sbírek objektivem Silvie Doležalové - Lob des mittelalterlichen Alltagslebens: Ein Blick in archäologische Sammlungen durch das Objektiv von Silvie Doležalová. Brno.

MICHNA, P. J., 1977: K vývojové a typologické charakteristice moravských středověkých kachlů - Zur entwicklungsmässigen und typologischen Charakteristik der mährischen mittelalterlichen Kacheln, Sborník památkové péče v Severomoravském kraji / Státní památková péče v Severomoravském kraji 3, $7-44$.

MIKA, N., 2000: Przejęcie księstwa raciborskiego przez władcę opawskiego Mikołaja II. In: Opava. Sborník k dějinám města 2, 11-14. Opava.

MILESON, S. A., 2009: Parks in Medieval England. Oxford. 
MLÍKOVSKÝ, J., 2003: Zvířata a jejich role na raně středověkém hradě Stará Boleslav (střední Čechy) Animals and their role in the Early Medieval stronghold Stará Boleslav (central Bohemia), Mediaevalia archaeologica 5, 347-365.

- 2005: Evidence for hawking in early Medieval Czechia, Buteo 14, 53-56.

MOSKAL, K., 2010, Calor amicus, czyli o kaflu i piecu. Kraków.

- 2012: Kafle w zbiorach Muzeum Historycznego Miasta Krakowa. Kraków.

NEDVĚDOVÁ, M.-KOLÁR, J., edd., 1983: Próza českého středověku. Praha.

NEKUDA, V.-REICHERTOVÁ, K., 1968: Středověká keramika v Čechách a na Moravě. Brno.

NOŽIČKA, J., 1957: Přehled vývoje našich lesů. Praha.

NÝVLTOVÁ-FIŠÁKOVÁ, M., 2007: Nález chrta na hradisku Chotěbuz-Podobora - Greyhound find from Chotěbuz-Podobora hillfort, Těšínsko 50, 29-31.

- 2011: Zvířecí osteologický materiál z hradu Skály (horní hrad) - Osteologisches material tierischer Herkunft von der burg Skály (obere burg). In: Hrad jako technický problém (Měř́nský, Z., ed.), 47-57. Brno.

ORNA, J., 2005: Gotické a renesanční kachle ve sbírkách Západočeského muzea v Plzni. Plzeň.

PAVLÍK, Č., 1992: Gotické a goticko-renesanční kachle z hradu Rožnova. Praha - Basel.

- 2007: Gotické a renesanční kachle pod Ždánickým lesem - Gothic and Renaissance tiles in the Ždánický Forest region, Sborník Regionálního muzea v Mikulově RegioM, 74-90.

- 2008: Náboženské motivy. In: Krása, která hřeje. Výběrový katalog gotických a renesančních kachlů Moravy a Slezska - Schönheit, die wärmt. Gotische und renessainzeitliche Kacheln aus Mähren und Schlesien (Menoušková, D.-Měř́nský, Z., edd.), 10-35. Uherské Hradiště.

PAVLÍK, Č.-VITANOVSKÝ, M., 2004: Encyklopedie kachlů v Čechách, na Moravě a ve Slezsku. Ikonografický atlas reliéfů na kachlích gotiky a renesance. Praha.

- 2009: Invalidé na středověkých kachlích - Invaliden auf mittelalterlichen Kacheln, AH 34, 245-254.

PÍREK, M., 2014: Psy a ich chov v stredovekej spoločnosti so zvláštnym zameraním na územie Uhorského královstva - Dogs and their breeding in Middle Ages society with special attention to the territory of the Hungarian Kingdom, HŠ 48, 125-136.

- 2015: Psy a ich chov v stredovekej spoločnosti. In: Člověk a svet zvierat v stredoveku (Dvořáková, D. a kol., edd.), 197-217. Bratislava.

POSPIESZNA, B., 2013: Kafle i piece kaflowe w zbiorach Muzeum Zamkowego w Malborku. Malbork.

PRIX, D., 1994: Páni z Krnova a Lobenštejna na středověkém Opavsku, Acta historica et museologica 1, 43-58

PROFANTOVÁ, N., 2008: Byzantské nálezy v 6.-11. století v Čechách a na Moravě. In: Země Koruny české a východní Stř̌edomoří ve středověku a novověku (Charvát, P.-Maříková-Vlčková, P., edd.), 73-120. Praha.

RAKUŠAN, C., 1999: K počátkům českého loveckého práva, Silva Bohemica 9, 16-17.

REDOLFI, M., 2002: Die mittelalterliche Jagd und ihre Darstellung im Codex Manesse, Zeitschrift des Schweizerischen Burgenvereins, Band 7, Heft 3, 61-70.

RICHTEROVÁ, J., 1982: Středověké kachle. Praha.

ROYT, J.-ŠEDINOVÁ, H., 1998: Slovník symbolů: kosmos, příroda a člověk v křest’anské ikonografii. Praha.

RÖSENER, W., 1997: Jagd, Rittertum und Fürstenhof im Hochmittelalter. In: Jagd und höfische Kultur im Mittelalter (Rösener, W., ed.), 123-148. Göttingen.

SAMSONOWICZ, A., 1991: Łowiectwo w Polsce za czasów Piastów i Jagiellonów. Studia i Materiały z Historii Kultury Materialnej 62. Wrocław - Warszawa - Kraków - Łódź.

- 1994: Uwagi o regale w Polsce piastowskiej (na przykładzie regale łowieckiego i rybackiego), Kwartalnik Historyczny CI, č. 4, 3-12.

- 1995: Łowy władcow - łowy poddanych. In: Łowiectwo w tradicji i kulturze międzynarodowe sympozjum Pułstuck 94. Zarząd Glowny Polskiego Związku Łowieckiego, 60-68. Warszawa.

- 2011: Łowiectwo w Polsce Piastów i Jagiellonów. Warszawa.

SAWINA, D., 2015: Rycerz, wojownik, poeta. Okołoliterackie aspekty kultury rycerskiej na Śląsku i jej czeskie inspiracje - The knight, the warrior and the poet. Literary aspects of the chivalric culture in the Silesia and its Bohemian inspirations, Meluzyna II, č. 1, 41-58.

SOUKUPOVÁ, M.-SOUKUP, M., 2017: 035 Komorové kachle s žánrovými motivy - lovecká scéna se sokolníkem. In: Svět kachlových kamen. Kachle a kachlová kamna severozápadních Čech (Šrejberová, J., ed.), 137-138. Most.

SOUKUPOVÁ, M.-SOUKUP, M.-WIESNEROVÁ, E., 2017: 036 Komorové kachle s žánrovými motivy jelen. In: Svět kachlových kamen. Kachle a kachlová kamna severozápadních Čech (Šrejberová, J., ed.), 138. Most. 
STEHLÍKOVÁ, D., 1999: Umělecká řemesla mezi vrcholnou gotikou a renesancí. Hesla č. 117-121. In: Od gotiky k renesanci. Výtvarná kultura Moravy a Slezska 1400-1550. Sv. IV, 207-210, 225-227. Brno.

STRAUSS, K., 1966: Die Kachelkunst des 15. bis 16. Jahrhunderts in Deutschland, Österreich und der Schweiz I. Strasburg.

- 1983: Die Kachelkunst des 15. bis 17. Jahrhunderts in europäischen Ländern. III. Teil. München.

SZCZEPANOWSKA, K., 2014: Sceny polowań na nowożytnych kaflach z Gdańska. Charakterystyka przedstawień na podstawie kafl i z wybranych stanowisk - Hunting scenes on modern tiles from Gdańsk. Characteristics of presentations on the grounds of tiles from selected sites, Gdańskie Studia Archeologiczne 4, 135-156.

ŠIKULOVÁ, V., 1999: Umělecká řemesla mezi vrcholnou gotikou a renesancí. Hesla č. 122-128. In: Od gotiky k renesanci. Výtvarná kultura Moravy a Slezska 1400-1550. Sv. IV, 227-229. Brno.

ŠIMŮNEK, R., 2008: Rezidenční dvory české šlechty v pozdním středověku. In: Dvory a rezidence ve středověku II. Skladba a kultura dvorské společnosti (Dvořáčková-Malá, D.-Zelenka, J., edd.), 285-325. Praha.

ŠÍN, L., 2014: Člověk 9. až 12. století na Olomoucku. Rkp. disertační práce Ústavu antropologie PF MU, školitel prof. PhDr. Josef Unger, CSc., Brno.

ŚLAWSKI, G. a T., 1994: Garncarstwo i kaflarstwo na ziemiach polskich od średniowiecza do czasów vzpołczesnych. Materiały z konferencji Rzeszów 21.-23. IX 1993. Rzeszów.

TEREN, Š.-RUSINA, I.-MOLNÁR, L., 1988: Lov a zver vo výtvarnom prejave. Bratislava.

TOMKIEWICZ, S.-INQUIST, H., 1884: Szczątki średniowiecznego zameczku zwanego Wołek w księstwie oświęcimskim, Sprawozdania Komisji do Badań Historii Śtuki w Polsce III, č. 1, 1-6.

TRACHTOVÁ, N., 2008: Les v životě středověkého člověka na příkladu křivoklátského loveckého hvozdu Woods in the life of medieval people on example of royal forest by Křivoklát. Rkp. nepubl. diplomové práce Ústavu českých dějin FF UK, ved. práce prof. PhDr. Josef Žemlička, DrSc., Praha.

TREU, U., 1981: Physiologus: Frühchristliche Tiersymbolik. Berlin.

TYMONOVÁ, M., 2009: Stř̌edověké reliéfní kachle jako pramen hmotné kultury (Slezsko) - Mittelalterliche Reliefkacheln als Quelle der Sachkultur (Schlesien), AH 34, $209-223$.

- 2011: Gotické a renesanční kachle ze slezských hradů - Gothic and Renaissance Tiles from Silesian Castles. Díl I.-III. Rkp. nepubl. disertační práce na ÚAM FF MU, vedoucí práce doc. PhDr. P. Kouřil, CSc., Brno.

- 2014: Výroba kamnářské keramiky v českých zemích a dílna v Opavě - Belege für die Herstellung von Ofenkeramik in den Ländern Böhmens und eine Werkstatt in Opava, AH 39, 155-175.

VANÍČKOVÁ, A., 2012: Lov ve vrcholném středověku s přihlédnutím k archeozoologickým závěrům. Rkp. bakalářské práce na Archeologickém ústavu FF Jihočeské univerzity v Českých Budějovicích, vedoucí práce Ing. Lenka Kovačiková, Ph.D., České Budějovice.

VANÍČKOVÁ-ŽEMLIČKOVÁ, A., 2015: Lov zvěře v raném středověku - Hunting in the Early Middle Ages. Rkp. nepubl. diplomové práce Ústavu pro archeologii FF UK, ved. práce prof. PhDr. Josef Žemlička, DrSc., Praha.

VAŘEKA, P., 1997: Záchranný archeologický výzkum pozdně středověkého domu v Sedlčanech - předběžná zpráva - Rescue excavations of the late medieval house in Sedlčany - preliminary report, ASČ 1, 399-406.

VAŠICA, J., 2014: Literární památky epochy velkomoravské. Praha.

VELČEV, S., 2015: Král a jeho šlechtic, šlechtic a jeho král. Pohled do staročeské rytířské epiky 14. století. Rkp. nepubl. magisterské diplomové práce Historického ústavu FF MU, ved. práce Mgr. Tomáš Borovský, Ph.D., Brno.

VERDON, J., 2003: Volný čas ve středověku. Praha.

WAINGERTNER, B., 2004: Polowania w Polsce Jagiellonów. Z dziejów łowieckiegi i dworskiego obyczaju, Przegład Nauk Historycznych III, č. 2(6), 177-183.

WINTER, Z., 1892: Kuchyně a stůl našich předků. Praha.

ZAVŘEL, J., 1998: Středověké kachle ze Seminářské zahrady na Petř́ně. Kamna Čeňka z Klinštejna? Mittelalterliche Kacheln auf dem Seminar-Garten auf dem Laurenziberg. Backsteinofen Čeněk von Klinštejns?, Archaeologica Pragensia 14, 217-228.

ZELENKA, J., 2014: Od bitky k rytířskému zápolení. In: Dvořáčková-Malá, D.-Zelenka, J. a kol., Přemyslovský dvůr. Život knížat, králů a rytíř̉ ve středověku, 403-412. Praha.

ZOTZ, T., 1997: Beobachtungen zu Königstum und Forst im frühem Mittelalter. In: Jagd und höfische Kultur im Mittealter (Rösener, W., ed.), 94-122. Göttingen.

ŻEMIGALA, M., 1987: Ogrzewanie piecowe na zamku w Bolesławcu nad Prosą w XIV-XVII w. Wrócław Warszawa - Kraków - Łódź. 
ŽEMLIČKA, J., 1997: Čechy v době knížecí. Praha.

- 2002: Počátky Čech královských: 1198-1253. Proměna státu a společnosti. Praha.

- 2004: Peruc v mýtech a dějinách. Sborník př́íspěvků k mileniu setkání knížete Oldřicha s Boženou. Peruc.

- 2005: Přemyslovci. Jak žili, vládli, umírali. Praha.

- 2012: Česká krajina ve středověké transformaci - The Czech Landscape in Medieval Transformation, Mediaevalia Historica Bohemica 15, č. 1, 7-43.

- 2012a: K pozemkové výbavě české nobility ve starším středověku - On the Landed Property of Czech Nobility in the Early Middle Ages, ČČH 110, 189-233.

ŽEMLIČKOVÁ, A., 2012: Lov ve vrcholném středověku s přihlédnutím k archeozoologickým závěrům. Rkp. nepubl. bakalářské práce Archeologického ústavu FF Jihočeské univerzity v Českých Budějovicích, ved. práce Ing. Lenka Kovačiková, Ph.D., České Budějovice.

\section{Zusammenfassung}

\section{In Tschechisch-Schlesien entdeckte Kacheln mit dem Motiv der Jagd und ihre Provenienz}

Die Jagd hat im Leben der privilegierten Gesellschaft eine wichtige Rolle gespielt, worauf zahlreiche Quellen historischer und ikonographischer Natur hindeuten. Die elitäre Bedeutung dieser Tätigkeit belegen die im Codex Mannesse enthaltenen Illuminationen (Abb. 1) sowie die zeitgenössischen Handbücher über Jagdtechniken von Gaston Phébus (Abb. 2) oder das Falkenbuch von Friedrich II. (Abb. 3). Themen aus dem Jagdmilieu waren sehr populär und inspirierten deshalb auch die Schöpfer der Reliefverzierungen von Kachelöfen. Kacheln mit Jagdszenen waren sowohl in den Ländern Böhmens, als auch in Deutschland oder Polen verbreitet, und zwar in unterschiedlichen sozialen Milieus (Herrensitze, Städte und Klöster). Für die zweite Hälfte des 15. Jahrhunderts sind sie auch in Tschechisch-Schlesien belegt, und zwar in einem Fundkomplex von Burg Cvilin (Lobenstein, Schellenburg) bei Krnov (Jägerndorf) und im ungefähr zwanzig Kilometer von ihr entfernten Opava (Troppau), wo man anhand der aus einer petrographischen Analyse gewonnenen Ergebnisse ein Produktionszentrum vermutet.

Insgesamt wurden drei Grundmotive identifiziert, davon zwei im Konvolut von Burg Cvilin. Sie zeigen Falkner zu Pferde in der Begleitung von Hunden (1. Gruppe: 1. Variante mit Hirsch und einem Hund - Probe 1, Abb. 4; 2. Variante mit zwei Hunden - Probe 2, Abb. 5) und dann selbständige Darstellungen von Hirschen (2. Gruppe: 1. Variante mit nach vorne schauendem Hirsch - Probe 3 aus gröberem Ton, Abb. 5 und Probe 4 aus feinerem Ton, Abb. 6; 2. Variante mit nach hinten gewandtem Kopf - Probe 5, Abb. 7). Alle Motive verbindet die Beiwerkverzierung in Form von Sträuchern oder Bäumen mit tropfenförmigen Blättern, die auch auf Kacheln mit galanten Szenen vorkommen (Probe 6, Abb. 8), und in dem Motiv Zweikampf mit Schwertern (Abb. 9), mit denen die höfische Kultur belegt wird. Das letzte Grundmotiv wurde auf einer Kachel aus Opava - Oberer Markt wiedergegeben und zeigt die Hetzjagd auf einen Hirsch (Abb. 10). Die Kachel wurde für eine Analyse nicht zur Verfügung gestellt.

Die nächste Analogie zu den Exemplaren mit Hirsch stellt ein braun glasiertes Fragment von einer Grabung auf der ehemaligen Piastenburg in Ratibor dar (Probe 7, Abb. 11), ferner auf einer Kachel mit Falkner vom Kastell Gorzyczki, die nicht analysiert wurde (Abb. 12). Beide Fragmente weisen die gleiche Vegetation mit tropfenförmigen Blättern und eine ikonographisch vergleichbare Handschrift auf. Petrographisch unterscheidet sich jedoch die von der Ratiborer Kachel genommene Probe von der Probe von Burg Cvilin durch die jeweilige Materialzusammensetzung (Abb. 13). Da in der Region Opava lediglich in Opava eine Hafnerproduktion belegt ist, kann man die Werkstatt in der dortigen Krnovská-Straße, in der bis zum Beginn des Dreißigjährigen Krieges Kacheln hergestellt wurden, am ehesten als Entstehungsort der Kacheln ansehen. Diese Schlussfolgerung hat lediglich hypothetisch Gültigkeit, da die relevanten Fundkomplexe, die eine Hafnerproduktion indizieren, diese Hypothese nicht eindeutig stützen. Der Vertrieb von Kacheln aus der lokalen Werkstatt wird durch andere Motive angedeutet, etwa dem 
Motiv der thronenden Madonna oder durch Fragmente mit vegetabiler Rahmung, die in auf Burg Cvilin und in Opava in der Kolářská-Str. Nr. 13 gefunden wurden.

Auf die Frage, wer auf Burg Cvilin einen Kachelofen in Auftrag gegeben hat, gibt es keine eindeutige Antwort. Unter der Annahme, dass ein mit Jagdszenen verzierter Ofen auch im Hinblick auf die Lebensdauer eines Ofens (20-30 Jahre) mit Ankunft des neuen Besitzers der Burg im Jahr 1524 entfernt wurde, käme die Adelsfamilie Schellenberg in Betracht, die das Jägerndorfer Lehen im Jahr 1493 erwarb und bis zum Jahr 1517 auch die Herrschaft Vodislav innehatte. Es ist jedoch nicht ausgeschlossen, dass auch der Troppauer Fürst Johann IV. Auftraggeber war, der auch das benachbarte Ratibor verwaltete.

Der vorliegende Beitrag entstand im Rahmen des Förderprojekts GA17-13967S Quellen und Verbreitung ausgewählter Handelswaren der Keramikproduktion des Hoch- und Spätmittelalters.

Mgr. Martin Hložek, Ph.D., Ústav archeologie a muzeologie Filozofické fakulty Masarykovy univerzity, Arna Nováka 1,602 00 Brno, Česká republika, mhlozek@seznam.cz

PhDr. et PhDr. Markéta Tymonová, Ph.D., Ústav archeologie Filozoficko-přírodovědecké fakulty Slezské univerzity v Opavě, Bezručovo náměstí 13, 74601 Opava, Česká republika, marketa.tymonova@fpf.slu.cz 
